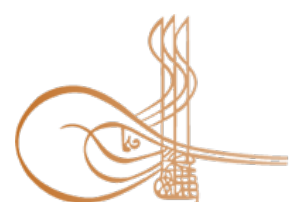

www.turkishstudies.net/history
Turkish Studies - Historical Analysis

eISSN: 2667-5552

Research Article / Araştırma Makalesi

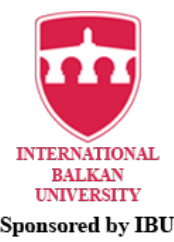

Sponsored by IBU

\title{
1917 Bolşevik Devrimi ve 1923 Türk Devrimi’nin Ardından Lenin ve Atatürk Figürlerinin Propaganda Afişlerindeki Yeri
}

\author{
The Place of Lenin and Atatürk's Figures in Propaganda Posters Following the 1917 Bolshevik \\ Revolution and the 1923 Turkish Revolution
}

\author{
Samet Yerköy*
}

\begin{abstract}
To increase the number of people who believe in their ideology and thoughts, propaganda means the influence of people, especially the sovereign powers in various ways; while carrying out its activities with technological developments in every period, it closely followed these tools and reinforced its effect with the help of these tools. The manipulative feature of propaganda was understood during the First World War, and this feature was further developed and was accompanied by mass media in the Second World War. First World War, after the establishment of totalitarian governments in Europe, in 1917, during the recycling of stone in Europe and The United States of America continent the made the Bolshevik Revolution, in 1923, the importance of propaganda in the Republic of Turkey's establishment can not be denied. On the other hand, both Ataturk and Lenin used propaganda, especially posters, to adopt their regimes and presented their portraits to the public through these posters. In this study, the concept and history of propaganda were discussed and the Russian and Turkish Revolutions, two separate revolutions that took place in 1917 and 1923 were examined historically. The propaganda posters of the leader of the Bolsheviks Vladimir İlyich Ulyanov's (Lenin), who took over after capturing the Petrograd Winter Palace in 1917; and the posters of Mustafa Kemal Ataturk, who became the founder and leader of the Turkish Republic after the Turkish War of Independence in 1923 were analized by Roland Barthes semiotic analysis method. At the end of the study, it was determined that both leaders were depicted as a hero on posters and pioneered the revolutions in the country. In the propaganda posters of Lenin, after the Bolshevik Revolution of October 1917, Lenin's struggles against the Russian tsarist family, capitalists and clergymen are at the forefront. These people were seen as obstacles to the revolution and great efforts have been made to liquidate them. At the same time, the Communist Party founded by Lenin was another theme that was frequently covered in Lenin's propaganda posters. The Soviet people were asked to join the party and it was pictured that the great victory would be achieved only by uniting the whole nation under the leadership of Lenin. In Ataturk's propaganda posters, the reforms that Ataturk realized in the country after the Turkish National Struggle are in the foreground. However, another prominent factor is that those who opposed Ataturk's reforms are depicted as a creature in the posters. On the other hand, the value and importance that Ataturk gave to the Turkish women was also found in the posters examined within the scope of the study.
\end{abstract}

\footnotetext{
* Doktora Öğrencisi, İstanbul Üniversitesi, İletişim Fakültesi, Gazetecilik Anabilim Dalı PhD Candidate, Istanbul University, Faculty of Communication, Department of Journalism ORCID 0000-0002-2682-4986

yerkoysamet@gmail.com

Cite as/ Atıf: Yerköy, S. (2020). 1917 Bolşevik Devrimi ve 1923 Türk Devrimi’nin ardından Lenin ve Atatürk figürlerinin propaganda afişlerindeki yeri. Turkish Studies - History, 15(2), 751-774. https://dx.doi.org/10.29228/TurkishStudies.42223

Received/Geliș: 21 March/Mart 2020

Accepted/Kabul: 20 June/Haziran 2020

Copyright $($ INTAC LTD, Turkey

Checked by plagiarism software

Published/Yayın: 25 June/Haziran 2020

CC BY-NC 4.0
} 
Structured Abstract: Introduction and Purpose of the Study:

Propaganda has always been used as an instrument of control and conformity by the dominant social power. Today, propaganda methods are frequently used in both authoritarian and democratic governments. The propaganda activities that started to be used in the First World War reached the peak of its use in the Second World War.

The study is an exploratory research due to the low number of examples that can be regarded as a premise on the subject. At the end of the October Revolution took place in Russia in 1917, the Bolshevik leader Lenin took over the government from the Russian Provisional Government. Ataturk has managed to reestablish with great struggles the new Republic of Turkey that lost the lands and independence in the First World War. Within the scope of the study it was examined how these two leaders are depicted on the posters and what their features are highlighted. The role of the posters in the adoption of the ideologies of these two leaders to the society was analyzed. In the study 8 propaganda posters, 4 of Lenin and 4 of Atatürk, were analyzed by semiotic analysis method.

\section{Conceptual / theoretical framework on the subject of study:}

In the study, firstly, the meaning and history of the propaganda were examined. The use of propaganda in its current sense has been started in the First World War. It is important to know its history to understand why propaganda has been used so often in great wars and important events in history. At first, the most important propaganda tools were newspapers and posters. Posters were used for propaganda purposes during the First World War. The function of the posters used in the war is to inform, instruct and make suggestions about new opinions in the war. The main purpose of the posters is to comply with people's mentality and ideas or to manipulate their ideas positively or negatively.

In the October Revolution, which took place in Russia under the leadership of Lenin in 1917 , propaganda posters had an important place. The October Revolution is a popular revolution, led by Vladimir Lenin, which is described as the continuation of the Revolution in 1905. The 1905 Revolution was initiated entirely with public will, but the 1917 Revolution was carried out under the leadership of a party. The October Revolution was elaborately prepared by the Bolsheviks, which Lenin brought to his side after a strong resistance put forward. As a result, Lenin came to the fore as a folk hero and found his place in propaganda posters.

The Ottoman Empire, which ruled in Asia, Europe and Africa for 624 years, suffered heavy losses in the First World War and was under threat of losing state sovereignty. Important parts of the country's lands were occupied by the Entente States. Uprisings and civil resistance started in different parts of Anatolia against occupations, after which Mustafa Kemal Atatürk set foot in Samsun on 19 May 1919 to protect the public order. Ataturk made an important speech at the 19th Republican People's Party Grand Congress and he stated in his speech that the establishment of the Republic of Turkey has started after Ataturk set foot in Samsun. After the Turkish War of Independence, Ataturk was accepted as a leader of a newly born state and he was depicted as a person who transformed the country in propaganda posters.

Method:

The propaganda posters examined in the study were subjected to semiotic analysis, which is one of the qualitative research methods. The theories of dénotation and connotation of the French linguist Roland Barthes were discussed and the messages intended to be conveyed to the masses were examined in the posters. At the same time, which metaphors are used to create friend and enemy figures in the posters are also reviewed in the study.

Findings and Discussion:

The propaganda posters of Atatürk and Lenin were analyzed by Roland Barthes' semiotic method, the role of these two leaders in their own country against the opposing ideologies is examined in the propaganda posters. Especially the rich landowners, Tsarist and religious leaders, whom Lenin opposed in the country, were described as hostile elements in these posters. The same enemy example is depicted as everyone and all ideologies that opposed Ataturk's reforms. The propaganda posters examined in this direction are important in terms of showing the world view and the struggles of the leaders. On the other hand, it is concluded that the 
posters with the leaders of the two countries will contribute to this area because they are important examples of the posters that represent the general and produced with the same opinion.

\section{Conclusion and Suggestions:}

After the revolution of 1917, the founding leader of the Union of Soviet Socialist Republics was Lenin. Until this revolution, Russia had heavy and turbulent years. The 1905 Revolution first occurred, it was unsuccessful, and then the 1917 February Revolution was carried out and the Tsarist system was overthrown, and the Provisional Government came in its place. The Bolshevik ideology has never supported the Provisional Government and continued its activities actively under the leadership of Lenin, who was abroad until October 1917. Accordingly, when examining the propaganda posters with the figure of Lenin, it was seen that he was depicted as a "founding leader" and not a "comrade". In these posters, Lenin is regarded as a strong leader who saved the country from the Tsarist order and who carried out a great cleansing, and made the Soviet state known all over the world.

Ataturk was a soldier in the last periods of the Ottoman Empire. As a result of the intense struggles on the fronts and the Turkish War of Independence, he became the founding leader of the country. Ataturk was the founder leader of the new country in the posters. As a result of this analysis it was concluded that Ataturk was a strong, guiding leader for Turkish people and he was shown that he always used to try to take the country forward.

Keywords: Communication, Propaganda, Poster, Bolshevik, The Republic of Turkey, Ataturk, Lenin

Öz: İnsanların, özellikle de egemen güçlerin kendi ideoloji ve kanaatlerine inanan kişilerin sayısını çoğaltmak adına çeşitli araçlarla yaptıkları etki anlamına gelen propaganda; faaliyetlerini yürütmede kullandığı bu araçları her dönem teknolojik gelişmelerle beraber yakından takip etmiş ve bu araçların yardımıyla etkisini güçlendirmiştir. Propagandanın manipülatif özelliği Birinci Dünya Savaşı sırasında kavranmış ve bu özellik daha da geliştirilerek İkinci Dünya Savaşı'nda kitle iletişim araçlarıyla birlikte yürütülmüştür. Birinci Dünya Savaşı'nın ardından Avrupa'da totaliter hükümetlerin kurulmasında, 1917 yılında gerçekleștirilen Bolșevik Devrimi'nde, Avrupa ve Amerika Birleşik Devletleri kıtasında taşların yeniden dönüşümü esnasında, 1923 Türkiye Cumhuriyeti'nin kuruluş aşamasında propagandanın önemi yadsınamaz. Buna karşılık hem Atatürk hem de Lenin, propagandayı özellikle de afişleri, kurdukları kendi rejimlerini halka benimsetmekte kullanmış, kendi portrelerini bu afişler vasıtasıyla topluma sunmuşlardır. Çalışmada propaganda kavramı ve tarihçesi ele alınmış, 1917 ve 1923 yıllarında gerçekleşen iki ayrı devrim olan Rus ve Türk Devrimleri tarihsel açıdan incelenmiştir. 1917 yılındaki Petrograd Kışlık Sarayı'nın ele geçirilmesinin ardından yönetimi ele geçiren Bolşeviklerin lideri Vladimir İlyiç Ulyanov'un (Lenin) ve 1923 y1lında kurtuluş mücadelesinin ardından Türkiye Cumhuriyeti'ni kuran lider Mustafa Kemal Atatürk'ün propaganda afişleri Roland Barthes'ın göstergebilimsel çözümleme yöntemiyle analiz edilmiştir. Çalışmanın sonunda her iki liderin afişlerde bir kahraman olarak betimlendiği ve ülkede gerçekleştirilen devrimlere öncülük ettiği saptanmıştır. Lenin'in propaganda afişlerinde, Ekim 1917 Bolşevik Devrimi'yle beraber, Lenin'in Rus çarlık ailesinden kalanlar, kapitalistler ve din adamlarına karşı yürüttüğü mücadeleler ön plandadır. Bu kişiler devrimin engeli olarak görülmüş ve onların tasfiyesi için yoğun çaba sarf edilmiştir. Aynı zamanda Lenin'in kurduğu Komünist Parti, Lenin'in propaganda afişlerinde sıklıkla işlenen bir diğer tema olmuştur. Sovyet halkının partiye üye olması istenmiş ve tüm ulusun ancak Lenin önderliğinde birleşmesiyle büyük zaferin elde edileceği resmedilmiştir. Atatürk'ün propaganda afişlerinde, Milli Mücadele'nin ardından Atatürk'ün ülkede gerçekleștirdiği devrimler ön plandadır. Bununla beraber öne çıkan bir diğer unsur ise Atatürk'ün devrimlerine karşı çıkanların afişlerde bir yaratık olarak betimlenmesidir. Bir diğer yandan Atatürk'ün Türk kadınına verdiği değer ve önem de çalışma kapsamında incelenen afişlerde yer bulmuştur.

Anahtar Kelimeler: İletişim, Propaganda, Afiş, Bolşevik, Türkiye Cumhuriyeti, Atatürk, Lenin

\section{Giriş}

Tarih boyunca büyük devletler kuruluş aşamalarında, kendi görüşlerini yaymada, toplumsal mesajlar vermede ve savaş sırasında düşman tarafını güçsüz düşürmeye çalışmada propaganda yöntemine başvurmuşlardır. Gerek otoriter sistemlerin gerek modern siyasi sistem olan demokratik 
yönetimlerin kamuya hitap etme ve kamu iradesini hedeflenen görüşe çekmek için propagandayı siyasal ve toplumsal yaşamda sıklıkla kullanmaktadırlar.

İnsanoğlu geçmişten bugüne kadar duygu ve düşüncelerini başka bireylere aktarma ihtiyacı hissetmiş, iletişim kurmaya çalışmış, kendi tutum ve kanaatlerini karşısındaki kişiye aşılamaya çalışmıştır. Bu aşılama ve ikna çalışmaları söz konusu siyasal alan olduğunda daha güçlü bir ivme kazanmıştır. Siyasal iktidarı ele geçirmeye çalışanlar, hedefledikleri konuma gelebilmek için toplumları etkilemek, destekleri üzerine çekmek ve kitleyi istedikleri alana yönlendirmek için çaba göstermişlerdir. $\mathrm{Bu}$ amaç doğrultusunda propagandanın önemi anlaşılmış ve bu olgu kilit bir rol üstlenmiştir.

Propaganda olgusu gerek siyasal iletişim alanına gerekse akademik çalışmalara giriş süreci 20nci yüzyılın başlarına denk gelmektedir. Propaganda 1920'li yıllarda Nazi Almanyası'nda Hitler tarafından ve Bolşevik Hükümetin Rusya'da başa gelme ve ideolojilerini yaymada Lenin tarafindan aktif bir şekilde kullanılmıştır. Lenin, komünist ideolojiyi halka benimsetmek ve geniş sınırlara yaymak için çeşitli sloganlar ve semboller ile toplumun her kesimine ulaşmayı hedeflemiştir. Devrimin gerçekleştiği zamanlar sıklıkla broşürler, afişler ve gazeteler aktif bir şekilde kullanılmıştır. Nitekim Rus halkı arasında okur-yazar oranının düşük olması nedeniyle Marks ve Lenin'in ideolojik eserlerinin geniş kitleler tarafından kolayca anlaşılması için ajitatörler propaganda afişlerine yönelmiştir (Kenez, 2003: 112). Günümüzde ise bilim ve teknolojide yaşanan gelişmeler, toplumsal ve siyasal değişimler nedeniyle sürekli olarak değişime uğramıştır. Açıkça belirtilmese de propaganda; siyasal iktidarın mevcut ideolojisini ve bilgisini halka aktarmada, kitle iletişim araçlarında, otokrat ve demokratik yönetimlerin işleyişinde ve rızanın üretiminde her zaman büyük bir rol oynamaktadır.

Çalışma, konuya ilişkin öncül olarak sayılabilecek örneklerin az olmasından dolayı keşfedici bir araştırma niteliğindedir. Çalışmanın amacı 1917 yılında Rusya'da gerçekleşen Ekim Devrimi'nin sonunda yönetimi Geçici Hükümet'ten devralarak iktidara sahip olan Bolşevik lider Lenin ile, Birinci Dünya Savaşı'ndan yenik çıkarak topraklarını kaybetmek üzere olan Osmanlı İmparatorluğu'nun 1923 y1lında Türkiye Cumhuriyeti olarak yeniden meydana gelmesinde büyük rol oynayan Atatürk figürlerinin propaganda afişlerinde nasıl yer aldığını ortaya koymaktır. Bu iki liderin afişlerde nasıl betimlendiği ve ne gibi özelliklerinin ön plana çıkarıldığ da çalışmanın kapsamında incelenmiştir. $\mathrm{Bu}$ iki ülke liderinin ideolojilerinin topluma benimsetilmesinde afişlerin oynadığ 1 rol analiz edilmiştir. Bununla beraber çalışmada Lenin'in 4 adet (Yoldaş Lenin Dünyayı Pisliklerden Temizliyor, Lenin Yaşadı, Lenin Yaşıyor, Lenin Yaşayacak, Lenin Bayrağı Altında Zafere Doğru İlerleyin, Lenin Derken Partiyi İma Ediyoruz, Parti Derken Lenin'i İma Ediyoruz) ve Atatürk'ün 4 adet (İslam'ın Kurtarıcıları, 1922'de Başlayan Savaş Hala Devam Ediyor, Yeni Türk Harfleri ve Atatürk, İnkılaplar ve Atatürk) olmak üzere ve bu başlıklar altında toplamda 8 propaganda afişi göstergebilimsel analiz yöntemiyle incelenmiştir. Çalışmada öncelikle propaganda üzerine farklı görüşler incelenecek, ardından 1917 yılında Lenin liderliğinde Bolşevik Devrimi ve 1923 'te Atatürk liderliğinde Türk Devrimleri tarihsel olarak incelenecektir. Tarih sahnesinde büyük bir yer edinmiş bu iki figürün gerçekleşen devrimler sonucundaki yayınlanan propaganda afişlerindeki tezahürleri Roland Barthes'ın göstergebilimsel analiz yöntemiyle incelemeye tabi tutulacaktır.

\section{Propagandanın Tanımı ve Tarihteki Yeri}

Kitle iletişim araçlarıyla egemen ideolojiyi yaymak, topluma istenilen düşünceleri ekmek ve zihin yönlendirmek için kullanılan propaganda için farklı tanımlar mevcuttur. Kullanım alanı modern dünyada daha geniş sınırlara ulaşan propaganda, en yaygın siyasal iletişimde kitleleri etkilemek ve bireyleri manipüle etmek için kullanılmakta, aynı zamanda bireylerin kendi aralarındaki iletişimlerinde yer bulmaktadır.

Kamuoyu kavramının ortaya çıkmasıyla beraber propaganda olgusu da günlük hayatta yerini almış, etkinliğini artırmış ve insanların düşüncelerini değiştirme aracı olarak kendini göstermiştir. 
Propaganda kelimesi etimolojik olarak Latinceden gelmiş ve "propagare" fiilinden doğmuştur. "Propagare" fiili Latincede bahçıvanın taze bitki filizlerini yeni bitkiler üretmesi için toprağa ekmesi anlamına gelmektedir. Bundan dolayı propaganda kelimesi yeni görüşleri topluma ekmek ve onları yaymak anlamına karşı1ık bulmaktadır (Brown, 1992:11). Siyaset, iletişim ve sosyoloji disiplinleriyle bağlantılı olan propaganda kelimesi üzerine farklı tanımlamalar mevcuttur. Temel olarak ele alındığında propagandanın tanımı: "Bir öğreti, düşünce ya da inancı başkalarına tanıtma, benimsetme ve yayma amacıyla söz, yazı gibi yollarla gerçekleştirilen çalışma" (TDK Sözlük 1998:549) olarak ele alınmaktadır. Propaganda terimi en sade anlamda "belirli fikirleri yaymak ya da tanitmak" anlamına gelir (Jowett \& O'Donnell, 2012:2).

Terence (1962) propaganda sayılabilecek etkinliklerin çok eski tarihlere uzandığını, toplumsal yapıların oluşmasıyla başlayıp, bu yapılarda liderlerin ya da liderliği ele geçirmek isteyenlerin kendilerine destek bulabilmek amaciyla propaganda yöntemlerine başvurduklarını belirtmiştir. Buna bağlı olarak Mısır'da Eski Krallık ve Orta Krallık dönemlerinde firavunlar ve eşleri için inşa edilmiş Mısır Piramitleri, Firavun heykelleri ve süslemeleri, tarih öncesi kabilelerin sembollerle bezenmiş heykelleri, Antik çağda Yunan yöneticilerinin yaptırdıkları amfiteatrlar, Roma krallarının arenalardaki gladyatör savaşlarında kendilerini alkışlatmaları, güç ve otoritelerini geniş halk kitlelerine yaymaları örneklerini verir. Bu yapılar, etkinlikler ve eserler kitleleri etkilemek için birer arac1 görevi görmüşlerdir.

Terence (1962) bununla beraber propagandanın farklı bir anlam kazanmasının 18. Yüzyıl'ın sonunda meydana gelen Fransız Devrimi'ne dayandığını belirtmektedir. Başta Batı toplumu olmak üzere dönemin bütün Avrupa topraklarında siyasi, toplumsal ve ekonomik sonuçları olan Fransız Devrimi'yle beraber ulus devlet anlayışı güçlenerek hüküm sürmüş; din olgusu her ne kadar Orta Çağ'da Almanya'da yaşanan reformlar sonucu zayıflamış olsa da yönetim erkini elinde bulunduranların bu olguyu kullanma yetkileri tamamen ortadan kalkmıştır. Fransız Devrimi'nin ortaya çıkardığı ulus devlet anlayışı, "özgürlük, kardeşlik, eşitlik" görüşleriyle birleştirilmiş ve bu süreçte ortaya çıkan propagandaya günümüze kadar farklı anlamlar yüklenmiştir.

Fransız Devrimi'nin takip eden çalkantılı yıllarda propagandayı en etkili şekilde kullanan liderlerden biri de Napolyon Bonapart olmuştur. Fransa'nın içinde bulunduğu karmaşanın ardından ülkenin başına geçen Napolyon Bonapart, resim sanatını bir propaganda aracı haline getirmiştir. Kendi portrelerini ülkenin her yerine astırmış ve gücünün sembolü olarak Mısır ve Roma mimarisi tarzında büyük yapılar inşa ettirmiştir. En görkemli propagandası ise Notre Dame Katedrali'nde Papa VII. Pius'un elinden taç giymesi olmuştur. Kısa bir süre sonra Napolyon halkı etkilemenin en önemli yolu olan basının önemini anlamış ve basın yoluyla propaganda yöntemini yaygın bir biçimde kullanmaya başlamıştır. Gazetenin halkı etkileme gücünü çok iyi anlamış ve bunu en iyi biçimde kullanan ilk lider olarak kayıtlara geçmiştir. Basın üzerinde sansürü devam ettirirken, Moniteur Universel adlı gazetesi vasıtasıyla siyasal ve askeri amaçlarla propaganda yaptırmış ve istila ettiği ülkelerde dahi bu faaliyetine devam etmiş̧tir (Bektaş, 2002: 89).

Almanya, propagandada sinemanın gücünü anlamışlar, ancak propaganda aracı olarak sinemayı kullanmakta geç kalmışlardır. Birinci Dünya Savaşı'ndan yenik çıkan Almanya, bu yenilgiyi her zaman propagandanın yetersiz ve yanlış kullanımına mal etmişlerdir (İnceoğlu, 2015: 78). Nitekim propagandanın önemini kavrayan bir diğer kişi ise Nazi lideri Adolf Hitler olmuştur. Hitler, İkinci Dünya Savaşı'nda propagandayı etkin bir şekilde farklı araçlarla kullanmıştır. Hitler'in her daim süregelen Bolşevik ve Yahudi düşmanlığı, kaybedilen savaşın ardından zorla imzalanan Versay Antlaşması neticesinde propaganda fikrinin halka aşılanması hız kazanarak devam etmiştir. Nitekim Joseph Goebbels başkanlığında kurulan Propaganda Bakanlığı, Nazi düşüncesini toplumun her katmanına aşılamak ve bu düşüncenin etkili bir şekilde nüfuz etmesi için bütün kitle iletişim araçlarını devreye sokmuştur. Faşizm ideolojisinin aşılanması için o dönem kullanılan en etkin propaganda araçları başta radyo olmak üzere televizyon, afiş, broşür ve sinemadır (Bektaş: 125). 
Goebbels bu süreç içinde en etkin olarak radyoyu kullanmıştır. Radyonun tüm evlere ulaşabilmesi için ucuz radyo üretimine başlanmış ve böylece radyo Almanya'daki bütün evlere ulaşma imkânı bulmuştur. Alman radyolarında farklı dillerde de yayın yapılmış, aralarında Türkiye'nin de bulunduğu birçok ülkeyi düşmanlarına karşı kışkırtmaya çalışmıştır. Hitler ve Goebbels'e göre propaganda amaçlı kullanılacak araçlar ve üretilen mesajlar toplumun en düşük seviyedeki bir zekaya hitap edecek kadar yalın ve süslü kelimelerden uzak olmalıdır. Hitler, propagandanın gerçeği yansıtma gayesi olmaması gerektiğini, propagandacının amacına ulaşmak için yalana başvurabileceğini belirtmiştir (Hitler, 1998: 12).

Sovyetler Birliği Bolşevik iktidar liderliğinde, uluslararası alanda etkinlik gösteren kalıcı bir propaganda örgütü kuran ilk devlet olmuştur. 1917 Ekim Devrimi sonucu iktidarı ele geçiren Bolşeviklerin karşısında \%80'i okuma yazma bilmeyen bir halk, sanayisi güçsüz, ağırlık olarak köylü ve sefaletle boğuşan bir toplum bulunmaktaydı. İdeal bir Komünist toplum yaratmak isteyen Bolşevikler propaganda yöntemlerine sıkça başvurmuşlardır. Sovyet propagandası ülkenin her yerine yayılmış, köylerde okuma odaları kurulmuş, film gösterileri gerçekleştirilmiştir. Tüm propaganda faaliyetleri Agitrop olarak adlandırılan Komünist Parti Merkez Komitesi Ajitatif Propaganda Birimi'nin sıkı kontrolü altında ilerlemiştir (Jowett \& O'Donnell, 2012: 229). Devrimden sonraki y1llarda ajitatif propaganda kapsamında festivaller ve tiyatro gösterileri düzenlenmiş, sokaklar afişlerle kaplanmıştır. 12 Nisan 1918 yılında Lenin tarafından yayınlanan "Dekret o Pamyatnikah Respubliki (Cumhuriyet Anıtları Hakkında Kararname)"1 neticesinde ülkedeki "Çarların ve uşaklarının" anıt heykelleri kaldırılmış, yerine devrimci ruhu taşıyan liderlerin anıtları propaganda amaçlı ülkenin önemli yerlerine dikilmiştir.

Bolşevik propagandasının ilk şartı, bilginin Marksist-Leninist teori açısından doğru olması gerektiği varsayımı olmuştur. Böylece doğru teorilere sahip olmayan basın araçlarına ve bilgiye erişim reddedilebilmektedir. Marksist-Leninist temel açısından doğru kabul edilmeyen bilgilerin, mesajın doğruluğu durumunda bile kamuoyundan gizlenebileceği sonucuna varılmaktadır. Bolşeviklere göre propaganda, eğitimin bir parçası olarak, politik bir eğitici çalışma olarak ifade edilmiştir. Lenin'in fikrine göre sosyalizmi inşa etmenin önündeki ana engel Rus halkının geri kalmışlığı olmuştur. Bu sorunu çözmek için de halkın eğitilmesi gerekliydi. Lenin ilk olarak Rus halkının okuma ve yazma öğrenmesini, ikinci olarak Batı medeniyetinin faydalarından yararlanabilmelerini ve üçüncü olarak da halkın sosyalizm fikrini öğrenmesini istemiştir. Bolşevik görüşe göre bilginin temellerinin incelenmesi ve Bolşevik fikirlerin yayılması birbirinden ayrılmaz iki kavram olmuştur. Böylece halkın ideolojik olarak yeniden işlenmesi, Sovyet devletinin oluşumunda ve Bolşevik politikanın yürütülmesinde kilit rol oynamıştır (Kenez: 8).

Başlangıçta Bolşeviklerin propaganda organizasyonu hakkında net planları olmamıştır. Sistem Beş Y1llık Plan'ın uygulandığı ve iç savaşın yaşandığı dönemde gelişmiştir. Propaganda faaliyetleri Bolşeviklerin devlet kurumlarını ele geçirmesinden ve kitle iletişim araçlarına sahip olmasından sonra ivme kazanmıştır. Gazete ve afişler aracılığıyla yoğun bir propaganda yürütülmüş, yazılı basın araçları Bolşevikler tarafından dikkatli bir denetime tabi tutulmuş ve Kızıl Ordu için önemli bir propaganda aygıtı işlevi görmüştür. Birinci Dünya Savaşı'ndan sonra Bolşevik propagandası diğer ülkelere kıyasla gözle görülür bir gelişme sergilemiştir. Sovyetler Birliği Lenin ve Stalin döneminde dünyanın ilk propaganda devleti olmuştur (Terence: 45).

\section{Propaganda Aracı Olarak Afişler}

Kullanılacak olan araç, propaganda faaliyetlerinin etkin bir şekilde yürütülmesi, geniş kesimlere ulaşarak başarı sağlaması için gereklidir. Propaganda kitleleri etkilerken kitle iletişim araçlarından faydalanmaktadır. Nitekim, insanlar üzerinde baskı kurma ve insanları manipüle etmede bu araçlar önemli bir rol oynamaktadır (Kuruoğlu, 2006:7). Kitle iletişim araçları olarak da

\footnotetext{
1 "Cumhuriyet Anıtları Hakkında Kararname", http://www.hist.msu.ru/ER/Etext/DEKRET/18-04-12.htm, [18.02.2020].
} 
sayabileceğimiz gazete, dergi, radyo, kitap, televizyon, afiş, sinema, resim, internet ve internetin gelişmesiyle ortaya çıkan sosyal medya aynı zamanda birer propaganda araçlarıdır. Bütün bu araçların ortaya çıkış ve yayılış süreçleri farklı olsa da hepsi egemen ideolojiye hizmet eden bir propaganda aracı olarak kullanılmıştır (Bektaş: 15).

Propaganda afişleri binlerce yıldır halkı bilgilendirmek, liderleri ve fikirleri desteklemek, olayların ve rejimlerin nüfuzunu güçlendirmek için kullanılmıştır. Çok eskiden taş duvarlara kazınırken 15.yy.dan sonra kağıtlara yazılmaya başlanılan afişler gittikçe sanat değeri olan birer propaganda ve reklam aracı haline gelmişlerdir (Ana Britannica, 1986:222). Afiş; "bir haberi, bir olayı, siyasal, sosyal, ekonomik, sanatsal ve kültürel açıdan topluma duyurmak amacıyla, değişik yüzeyler üzerine yapılan ve belirli boyutlarda köy, kasaba ve şehirlerin çeşitli yerlerine asılan duyurulardır" (Tepecik, 2002:77). Kısa ömürlü bir propaganda aracı olan afişin amacı topluma istenilen bilginin hızlı yolla aktarılması ve kitlelerin kısa yoldan manipüle edilmesidir. Köy, şehir, kasaba gibi yerleşim bölgelerinin en görünür yerlerine asılarak, insanlara belirli bir ideolojiyi devamlı olarak aşılamak için kullanılan kitle iletişim aracıdır. Afişte kullanılan yazı, renk ve semboller okuma yazma bilmeyen, kültür seviyesi düşük kitlelerin kolay anlaması için en basit şekle indirgenmiş ve böylece tarih boyunca, özellikle de Birinci ve İkinci Dünya savaşları sırasında etkili bir araç olmuştur. Afişin içinde gösterilen resimler ve illüstrasyonlar iletiyi basitçe anlatma özelliğine sahiptir. Afişler 20nci yüzyılın ilk yarısında siyasal alanda propagandanın en gelişmiş araçlarından biri haline gelmiştir (Topuz: 1991: 160).

Propaganda veya kitle ikna kampanyaları kamuoyunu etkileme amacı taşımaktadır. $\mathrm{Bu}$ amacı gerçekleştirmek için tasarlanan ilk afiş, 16. yüzyılın ilk yarısında Almanya'daki Protestan Reformu sırasında basılmıștır (Seidman, 2008:3). Ancak duvar resimleri ve Orta Çağ gravürleri afiş̧ sanatının ilk örnekleri sayılmaktadır. Afişin günümüz şekline benzemese de eski Mısır'da afiş tarzı örnekler bulunmaktadır. Antik Mısır'da kaçan kölelerin yakalandığını gösteren bilgi amaçlı ilanlar, Antik Yunan ve Roma'da oynanan tiyatro oyunlarını halka duyuran broşürler modern afişlerin atası sayılmaktadır (Bektaş: 23).

Afişlerin propaganda amaçlı kullanımı Birinci Dünya Savaşı dönemine denk düşmektedir. Bir savaş durumunda sorun, insanların nasıl harekete geçirileceği ve acil görev ve hedeflerden nasıl haberdar edileceğidir. İkinci Dünya Savaşı'nın başlangıcında Almanya, Rusya, İtalya ve Fransa gelişmiş bir propaganda makinesine sahipken müttefik ülkeler bu açıdan geride kalmıştır. Tüm bu ülkeler savaş durumunda politik ve sosyal birliğin muhafazasını sağlayan, moral ve coşkuyu sürdüren propagandanın önemini kavramışlardır. Savaşta kullanılan afişlerin işlevi ise savaştaki yeni görüşler hakkında bilgilendirmek, talimat vermek ve önerilerde bulunmaktır. Afişlerin ana gayesi, izleyicinin mantalite ve fikirlerine karşılık gelmeli veya fikirlerini olumlu ya da olumsuz bir şekilde manipüle etmektir. Fikir ve mesajın hedef kitle tarafından kolayca anlaşılması sağlanmalı, rasyonaliteden çok duygulara hitap etmelidir (Chambers, 1983: 54).

Birinci Dünya Savaşı'nda 1914 yılında İngiltere Savaş Bakanı Lord Kitchener orduya asker toplamak amacıyla "Ülkenin Sana İhtiyacı Var" sloganını kullanarak tasarladığı afişle halk üzerinde etki yaratmaya çalışmıştır. 1917 yılında Amerika Birleşik Devletleri ordusu için aynı amacı taşıyan "Sam Amca" figürüne sahip bir afiş üretilmiştir. İkinci Dünya Savaşı yıllarında Almanya, İtalya ve Sovyetler Birliği propaganda afişleri etkin bir biçimde kullanılmıştır. Aynı dönem yoğun bir biçimde kullanılan bir diğer propaganda aracı radyodan ve radyo aracılı̆̆ıyla verilen enformasyondan halkın kaçışı kolayken afişlerden uzaklaşmak kolay olmamıştır, çünkü insanlar caddelerin en görünür yerlerinde propaganda afişlerine maruz kalmışlardır. Nazi Almanyası'nın Halkı Aydınlatma ve Propaganda Bakanı olan Joseph Goebbels'in propagandacıları afişlerde yer alan görseli güçlü tutarak içerisinde verilen mesajın kolay kavranabilir olmasına dikkat etmiş ve bu mesajın bir slogan haline gelmesi için gayret göstermişlerdir (Topuz: 148). 
Sovyetler Birliği kurulduğu aşamadan itibaren propaganda afişlerini sıklıkla kullanmıştır. Rus Çarlığının yıkılışından Bolşevik Devrimi olarak adlandırılan 1917 Rus Devrimi'nde, Lenin ve Stalin'in ülkede gerçekleştirdiği her eylemde, iç ve diş politikada afişlere oldukça geniş yer verilmiştir. Yaratılmak istenen Sovyet insanı olgusu propaganda afişlerinde zuhur etmiş, özellikle de İkinci Dünya Savaşı döneminde halkı Nazilere karşı kışkırtmış, savaştan Sovyetlerin galip geleceği fikrini aşılamıştır. Moskova ve diğer şehirlerde yüzlerce sanatçı propaganda afişlerinin üretimi için çalışmışlar, ortaya çıkan bu afişler savaş devam ettiği sürece sokaklara, fabrikalara, okullara, çiftliklere, hastanelere, askeri kışlalara asılmıştır (Akarcalı, 2003: 213).

Türkiye'de afiş 19'uncu yüzyılın başından itibaren gelişme göstermiştir. Afiş̧in ilk örnekleri Osmanlı'nın son dönemlerinde ve Türkiye Cumhuriyeti'nin ilk yıllarında görülmeye başlamıştır. Afişler sokak, meydan gibi dış mekânlardan çok tiyatro girişleri, dükkân vitrinleri gibi iç mekânlarda sergilenmiştir. Batıda o yıllarda bir sanat dalı düzeyine erişmiş olan afişçilik alanında Türkiye'de herhangi bir etkinlik gerçekleşmemiştir (Akçura, 1994:28). Cumhuriyet'in ilk yıllarında inkılaplarının topluma tanıtılması ve benimsetilmesi için üretilen afişler ön plana çıkmıştır. Zamanla bu afişler yerini tüketim malları için üretilen reklam afişlerine ve tiyatro afişlerine bırakmıştır.

\section{Geçirmesi}

3. Rus Çarlığının Çöküşü ve Lenin Önderliğinde Bolşeviklerin İktidarı Ele

1917 Rus Devrimi olarak da adlandırılan Ekim Devrimi, Vladimir Lenin liderliğinde yürütülen ve 1905 Şubat Devrimi'nin devamı olarak nitelendirilen bir halk devimidir. 1905 Devrimi tamamıyla halk iradesiyle başlatılmış, ancak 1917 Devrimi bir parti öncülügüyle gerçekleştirilmiştir. Ekim Devrimi, Şubat Devrimi'nin aksine, Lenin'in ortaya koyduğu güçlü bir direnişin ardından kendi safına çektiği Bolşevikler tarafından özenle hazırlanmıştır (Orlov vd., 2017: 328).

Rusya'nın Birinci Dünya Savaşı'na katılımı, bir süreliğine toplumdaki sosyal çatışmaları ortadan kaldırmıştır. Toplumun tüm kesimi, savaşın başladığı ilk zamanlarda hükümete destek vermiş, ancak bu durum uzun sürmemiştir. Almanya ile yürütülen savaşta cephedeki yenilgiler, milyonlarca Rus vatandaşın hayatını kaybetmesi, halkın durumunun kötüye gitmesi ve geçim sıkıntıları kitleler arasında derin bir hoşnutsuzluk uyandırmıştır. 1915-1916 yıllarında ortaya çıkan ekonomik kriz ülke içindeki durumu daha da kötüleştirmiştir. Sanayi alanındaki dönüşümler genellikle cephenin ihtiyaçlarını karşılamaya yönelik geliştirilmiş, ancak bu tek taraflı dönüşüm tüketim mallarında yaşanan sıkıntıları ve yüksek fiyat artışını da beraberinde getirmiştir. Enflasyon yükselmiş, para birimi ruble değer kaybetmiş, ulaşım ve 1sınma sıkıntıları baş göstermiştir. Düşük kapasiteli demiryolları şehirlere ve askeri bölgelere kesintisiz bir şekilde yiyecek dağıtılmasını sağlayamamış, böylece gıda krizi ortaya çıkmıştır. Gerekli sanayi mallarına sahip olmayan köylüler, ev ürünlerini pazara sunmayı reddetmiştir. Bunun sonucunda ekmek sıraları oluşmuş, spekülasyon baş göstermiş, hükümetin kriz durumundan çıkma çabaları sonuçsuz kalmıştır (Orlov: 329).

Rusya'da ilk defa 1905 yılında Rus-Japon Savaşı sırasında vuku bulan devrim sonucu imparatorluk içinde oldukça farklı yeni siyasi akımlar oluşmuş, bu çeşitlilik de Çarlık rejiminin sürdürülmesini tehdit eder seviyeye gelmiştir. 1917 Şubat ayında ise yiyecek ekmek bulmanın zorluğunu neden gösteren siyasi örgütler, halkı ve askeri birlikleri arkalarına alarak gerçek anlamda bir ihtilal gerçekleştirmişlerdir. Çarlık hükümetinin devrilmesi sonucu Rus Devlet Duma'sı içinde Geçici Hükümet iktidarı ele geçirmiştir. Sovyet yetkilileri ve Duma temsilcileri arasında yapılan iki günlük müzakerelerden sonra 14 Mart'ta liberal bir geçici hükümetin oluşumuna ve Çar'ın istifasına karar k1lındı (Sürmeli, 2001: 1). Bunun sonucunda Geçici Devlet Duma's1 Komitesi görevini 12 kişilik Geçici Hükümete teslim etmiş, Çar II. Nikola tahtı terk etmek zorunda kalmıştır. İktidara gelen Geçici Hükümetin Almanya ile yapılan savaşı yürütmeye devam etme politikası halktan oldukça fazla tepki toplamıştır (Orlov: 370).

Aleksandr Kerensky liderliğinde Geçici Hükümet çalışmaya başlamış, İşçi ve Asker Vekilleri Sovyeti ile birlikte bir iktidar tablosu oluşturmuştur. Fakat bu iki taraflı iktidar arasında 
anlaşmazlıklar ve gerginlikler ortaya çıkmış, bütün yönetime karşıtlığını gösteren Bolşevik ve Menşevik örgütler de gerginliğin artmasına sebep olmuşlardır. Rusya'nın Birinci Dünya Savaşı'nda cephelerde aldığı yenilgiler ve uzayıp giden savaş hali halk üzerinde büyük hoşnutsuzluklar doğurmuştur. Bununla birlikte işçi grevleri ve köylü hareketleri eş zamanlı olarak artmıştır. Ülke içinde milli hareketler güçlenmiş, Orta Asya'daki yerel halklar Rusya'ya karşı ayaklanarak kendi bağımsızlıklarını kazanmak istemişlerdir. Devrimci ajitatörler yönetimin yaptığı bütün gafları iktidar seçkinlerinin itibarsızlaştırılması için kullanmışlardır. Menşevikler ve Sosyalist Devrimciler savaşın kısa süreli durdurulması ve demokratik bir barışın sağlanması çağrısını yaparken; Lenin liderliğindeki Bolşevikler Çarlık hükümetinin devrilmesini isteyerek halka bu emperyalist savaşın vatan savaşına dönüştürülmesi çağrısını yapmıştır. Başta sayıca az olan Bolşevikler, Lenin'in ekmek, hürriyet, barış ve "Bütün İktidar Sovyetlere" söylemleriyle gücünü günden güne arttırmışlardır (Sürmeli: 2001, 2-3). 16-18 Temmuz tarihlerine Petrograd'da Bolşevikler, hükümeti devirmek için bir ayaklanma gerçekleştirmişlerdir, fakat bu başkaldırı Kerenski tarafından bastırılmıştır. Bolşeviklerin bu yenilgisi sonucu Lenin ve Troçki yurtdışına kaçmışlar, Ekim Devrimi'ne kadar dönmemişlerdir.

1917 yılında Şubat olayları sırasında otokrasinin düşmesinden sonra iktidar, yerel konseylerin hüküm sürdüğü bölgelerde güçlü bir desteğe sahip olmayan Geçici Hükümete geçmiştir. Savaş devam ederken ülkede artan gıda krizi ile desteklenen bir iktidar krizi büyümüştür. Lenin bu devrimi göçmen olarak yaşadığı İsviçre'de öğrenmiş, hızlı bir şekilde kendisi gibi diğer siyasi göçmenlerle birlikte Petrograd'a dönüş yapmıştır. 3 Nisan 1917 yılında devrimci aktivistleri taşıyan tren Petrograd'a ulaşmış, hemen ertesi gün Lenin savaş ve devrim hakkındaki tezlerini "Nisan Tezleri" başlığı altında açıklamıştır. Bolşevik lider böylelikle sosyalistler için yeni bir politika oluşturarak büyük bir etki yaratmıştır. Nisan sonunda bu tezler, yerel Bolşevik yönetimler tarafından büyük destek görmüş ve parti programı haline getirilmiştir (Orlov: 328-330).

7 Nisan 1917 yılında "Bu Devrimdeki Proletaryanın Görevleri Hakkında" başlığı altında Pravda gazetesinde yayınlanan tezler şu maddeleri içermektedir.:

- $\quad$ Savaşı durdurmak,

- $\quad$ Sosyalist bir devrime geçiş yapmak,

- $\quad$ Geçici Hükümeti desteklememek,

- Tüm iktidarı Sovyetlere vermek,

- $\quad$ Sovyet Cumhuriyeti kurmak,

- Toprakları Sovyet köylülerine vermek,

- $\quad$ Finans ve üretim için iş kontrolü sağlamak,

- $\quad$ Parti programını değiştirmek,

- $\quad$ Yeni bir Enternasyonal yaratmak. ${ }^{2}$

Devrim ideolojisini halka aşılamaya çalışan Lenin'in ilk görevi sosyalist bir devrime geçiş yapmak olmuş; ilk başta sosyalizm ardından komünizme geçiş benimsenmiştir. Devrimin gerçekleştirilmesinde proletarya sınıfıyla birlikte köylülerin de büyük katkısı olmuştur. Bununla beraber savaşın kapitalizmin çıkar ve amaçlarına hizmet ettiğini düşünen Lenin, ilk olarak savaş1 bitirme yolunu aramıştır. İş̧̧i hareketine büyük engel oluşturabileceği düşüncesiyle burjuva sınıfına karşı büyük mücadele etmiş, iktidarın herhangi bir ortağı olmaksızın doğrudan sosyalist ideolojiye sahip Bolşevik hükümetine teslim edilmesi için çalışmıştır. Lenin proletarya ile halk, proletarya ile

\footnotetext{
2 " O zadaçah proletariata v dannoy revolyutsii", https://www.marxists.org/russkij/lenin/1917/0407a.htm, [21.02.2020].
} 
parti, proletarya ile köylü, parti ile parti örgütü, lider ile Sovyet iktidarının iç içe geçtiği bir yönetim biçimi oluşturmuştur.

\section{Büyük İmparatorluğun Çöküşü ve Atatürk Önderliğinde Kurulan Yeni Bir Cumhuriyet}

624 yıl Asya, Avrupa ve Afrika'da hüküm süren Osmanlı İmparatorluğu'nun Birinci Dünya Savaşı'nda aldığı yenilgiden sonra, devlet egemenliğini kaybetme tehdidi altında kalmış ve ülke topraklarının önemli kesimleri İtilaf Devletleri tarafından işgale uğramıştır. Bu işgallere karşı Anadolu'nun farklı bölgelerinde ayaklanmalar ve sivil direnişler başlamış, bunun üzerine Mustafa Kemal Atatürk 19 Mayıs 1919'da asayişi korumak için Samsun'a ayak basmıştır. Atatürk, 1927 yılında gerçekleşen Cumhuriyet Halk Fırkası Büyük Kurultayı'nda okuduğu nutkunda, Samsun'a ayak basmasıyla beraber Türkiye Cumhuriyeti kuruluşunun başladığını belirtmiş̧tir. Atatürk 3. Ordu Müfettişi olarak 19 Mayıs'ta Samsun'a ayak basar basmaz Anadolu'da siyasi ve askeri örgütlenmeyi sağlamak için çalışmalara başlamıştır (Çayc1, 2002: 85). Bunun üzerine Atatürk, ülke genelindeki direnişleri birleştirmek ve ülkeyi bu zor durumdan kurtarmak için 23 Temmuz 1919'da Erzurum ve 4 Eylül 1919'da Sivas'ta kongreler düzenlemiştir. Atatürk, Erzurum'daki kongre sırasında 7 Temmuz'da askerlik görevinden istifa ederek Osmanlı İmparatorluğu ile olan memuriyet bağlantısını kesmiştir (Atatürk, 1989: 64).

İtalya'da ve Balkan savaşlarında cephelerde büyük hizmetler sergilemiş ve ardından Sofya'ya ataşe olarak gönderilen Mustafa Kemal, 1915 yılının başında kendi isteğiyle savaşa katılmak için Türkiye'ye dönmüş, Boğazlarda ve Gelibolu'da kazanılan başarılarda büyük rol oynamıştır. Osmanlı ordusunun Çanakkale'de ve 1916 yılında Ruslara karşı doğu cephelerinde elde ettiği zaferler Atatürk'e büyük bir şöhret getirmiştir. Filistin ve Suriye'de İtilaf Devletleri'ne karş1 yürütülen çatışmalarda, özellikle de Halep’te mücadele içinde bulunan Atatürk, Mondros Ateşkes Antlaşması'nın imzalandığını duyduktan sonra İstanbul'a gitmiştir. Parlak ve başarılı bir askeri kariyerine rağmen Atatürk imparatorluktan fazla destek görmemiştir. Bunun nedeni ise padişah ve devlet erkanının milliyetçi ideolojilere karşı yürüttükleri mücadeledir. Halk hareketlerinin de imparatorluğun çözülmesine neden olan milliyetçilik ideolojisinin bir parçası olduğu düşünülmüş ve bu tarz ayaklanmalar engellenmek istenmiş, İtilaf Devletleri'nin Osmanlı'ya dayattığı maddeler kabul edilmiştir (Koloğlu: 1994: 63).

Başkentin umutsuz durumunu anlayan Mustafa Kemal, Anadolu'ya geçmeye karar vermiştir. Aralık 1918'de "Müdafaa-i Hukuk Cemiyetleri" adıyla ilk direnme grupları teşekkül etmişti. Bunlar ilk kez Trakya'da İzmir'de ortaya çıktı; Manisa'da ve Anadolu'nun diğer yerlerinde bunları başkaları izledi. Böylece düşmanın işgal ettiği alanlarda milli direnme hareketlerinin örneğini teşkil etti (Lewis, 1993: 246). Bütün bu gelişmeler sırasında Avrupa'nın "Hasta Adam" diye tasvir etmeye başladığı Osmanlı İmparatorluğu'nun tasfiyesi için Sevres Antlaşması hazırlanmış ve bu antlaşma hükümet tarafından imzalanmıştır. Ülkenin en önemli vilayetleri İtilaf Devletleri tarafından işgal edilmiştir. Samsun'a ayak basan Atatürk, hemen bir hareket örgütlemeye koyulmuş ve milli bir ordu kurmaya çalışmıştır. Mustafa Kemal'in yürüttüğü milli faaliyetlerin haberleri İstanbul'a ulaşmış, hükümet tarafında endişe uyandırmıştır. Harbiye Nazırı tarafından çağırılan Atatürk, olumsuz yanıt vererek görevinden istifa etmiş ve sivil kıyafetlerini giymeye başlamıştır.

23 Temmuz 1919'da Erzurum'da gerçekleştirilen toplantılar sonucu Mustafa Kemal kongre başkanı seçilmiş ve bu kongrede Misak-1 Milli sınırları belirlenmiştir. Erzurum Kongresi'nin üçüncü maddesinde; "Kuvayı milliyeyi amil ve iradeyi milliyeyi hâkim kılmak esastır." sözü ile Cumhuriyetin en açık ifadesi dile getirilmiştir (Ali, 1955: 32). Aynı yıl 4 Eylül'de Sivas'ta gerçekleşen kongrede "Anadolu ve Rumeli Müdafaa-i Hukuk Cemiyeti” örgütünün faaliyet alanları genişletilmiş ve bu örgüt yurt genelindeki bütün siyasi mücadelelerin lideri olmuştur. Kongre delegeleri İttihat ve Terakki Fırkasını yeniden oluşturmuşlar, toprak bütünlüğü ve ulusal bağımsızlığın korunması, düşman devletlere karşı silahlı direnişler başlatılması gibi kararlar 
almışlardır. Sadrazam Ali Rıza Paşa liderliğinde İstanbul hükümeti temsilcileri, Atatürk ve silah arkadaşlarıyla beraber görüşmeler gerçekleştirmiş ve bunun sonucunda Kemalistler ve programları hükümet tarafından tanınmıştır. Bu gelişmelerin ardından 12 Ocak 1920'de Osmanlı Meclis-i Mebusanı için seçimler yapılmış ve Kemalistler mecliste önemli yer elde etmişlerdir. Bu başarıyla beraber Erzurum ve Sivas kongrelerinde alınan bildirilere dayanan toprak bütünlüğü ve ulusal bağımsızlık üzerine temellenmiş Misak-1 Milli kabul edilmiştir (Berkes, 2013: 436).

Ülke genelinde ortaya çıkan milliyetçi hareketlerin aktif hale gelmesi İtilaf Devletleri'ni rahatsız etmiş, Ali Rıza Paşa istifa etmiş ve yerine Salih Paşa getirilmiştir. Milliyetçi cephedekilerin ve direniş hareketine öncülük edenlerin tutuklanması başlamış, buna tepki gösteren Meclis, süresi olarak tatil edilmiş ve 11 Nisan 1920 yllında padişah tarafından feshedilmiştir. Bunun üzerine Mustafa Kemal olağanüstü bir şekilde yeni bir meclis için seçim çalışmalarına başlamış ve bu meclis Ankara'da toplanmıştır. 23 Nisan'da Büyük Millet Meclisi olarak adlandırılan delege heyeti Ankara'da toplanmıştır (Lewis, 1993: 251). Yunan, Ermeni ve Fransız güçlerine karşı askeri mücadelelerini sürdüren Kuvayi milliye ordusu, hükümete karşı da bir mücadeleye girişmiştir. 1921 yılında imzalanan Sevr Antlaşması sonucu ülkede halk tarafından hükümete karşı bir tepki yağmış ve milli mücadeleye olan destekler artmaya başlamıştır. 1920-1922 yılları arasında Yunan güçlerle büyük savaşlar yaşanmış ve Yunan ilerleyişi Sakarya Nehri'ne kadar devam etmiştir. 24 Ağustos'ta Mustafa Kemal liderliğinde büyük bir savaş yapılmış ve Kuvayi Milliye ordusu büyük bir zafer elde etmiştir. Bu zafer sonucunda Büyük Millet Meclisi tarafından Atatürk'e "Gazi” unvanı ve Mareşal rütbesi verilmiştir (Çayc1, 2002: 155). Elde edilen Sakarya Zaferi sonunda Kemalistler ve milliyetçiler Türkiye'nin yeni hükümeti olarak tanınmıştır. Dumlupınar'da ve Doğu Trakya'da Yunanlılara karşı, Çanakkale'de de İtilaf Devletlerine karşı kazanılan zaferler sonucunda da İzmir işgalden kurtarılmış ve böylece Anadolu yeniden bir bütünlük kazanmıştır (Berkes: 480-485).

Türk hükümetiyle yapılan barış konferansı 20 Kasım 1922'de Lozan'da başlamıştır. Söz konusu konferansın en büyük özelliği günümüz Türkiye topraklarının bu antlaşmayla beraber yeniden kurulmasıdır. TBMM hükümeti Lozan Konferansı'na katılarak Misak-1 Milli hedefine ulaşmak, Ermeni ve Yunan sorunlarını çözmek ve kapitülasyonları ortadan kaldırmak istemiştir. Milli Mücadele süresince Müdafaa-i Hukuk örgütlerinin faaliyetleri sonucunda ve Ankara-İstanbul arasında yaşanan gergin ilişkiler neticesinde Türkiye'de cumhuriyetin ilan edilişi gerçekleşmiştir. Direniş boyunca Milli Mücadele'ye destek vermeyen İstanbul Hükümeti, mücadele zaferle taçlandırıldıktan sonra iktidarda kalmakta direnmiş ve Lozan Konferansı'nda Türkiye'yi temsil etmeye girişmiştir. Bu duruma TBMM sert bir tepki göstermiştir. Mustafa Kemal TBMM'de bu duruma ilişkin bir nutuk söylemiştir. Bu nutuk şaşılacak bir bilgi genişliği ve görüş yeniliğiyle saltanat ile hilafetin bir tarihçesidir. Saltanat, dünyasal bir egemenlikten başka bir şey değildir. Egemenlik ulusal geçtiği için "saltanat" diye bir şey artık yoktur (Berkes: 504). 1922'de saltanatın kaldırılması, Milli Mücadele'nin en başından beri devam eden Ankara ve İstanbul arasındaki iktidar savaşının Ankara lehine sonuçlanmasını göstermektedir.

Cumhuriyetin ilanı, Teşkilat-1 Esasiye Kanunu'nda yapılan bir değişiklik sonucu gerçekleşmiştir. 20 Ocak 1921'de "Hakimiyet bila kaydü şart milletindir. İdare usulü halkın mukadderatını bizzat ve bilfiil idare etmesi esasına müstenittir" ilkesini kesinlikle beyan ederek başlayan bir Teşkilat-1 Esasiye Kanunu kabul edilmiştir (Lewis, 1993: 236). Böylece Türkiye Devleti yönetim şekli Cumhuriyet olarak dönüşüme uğramıştır.

\section{Yöntem}

\section{1. Çalışmanın Amacı}

Bu çalışmada temel amaç; 1917 yılında Rusya'da gerçekleşen Ekim Devrimi'nin sonunda yönetimi Geçici Hükümet’ten devralarak iktidara sahip olan Bolşevik lider Lenin ile, Birinci Dünya Savaşı'ndan yenik çıkarak topraklarını kaybetmek üzere olan Osmanlı İmparatorluğu'nun 1923 yılında Türkiye Cumhuriyeti olarak yeniden meydana gelmesinde büyük rol oynayan Atatürk 
figürlerinin propaganda afişlerinde nasıl yer aldığını ortaya koymaktır. Bu iki liderin afişlerde nasıl betimlendiği ve ne gibi özellikleri ön plana çıkarıldığı da çalışmada incelenmiştir.

\section{2. Çalışmanın Önemi}

Söz konusu çalışma;

- Her iki ülke liderinin halk kahramanı olarak gösterilmesi ve kendi ulusunda rol model haline getirilmesine yönelik yürütülen çalışmalarda propaganda afişlerinin önemini ortaya çıkarması,

- I İki liderin ülkelerinde gerçekleştirdiği reform ve yeniliklerin propaganda afişlerine nasıl tezahür ettiğinin gösterilmesi,

- $\quad$ Propaganda afişlerinin Rus Çarlığının yıkılarak yerine Bolşevik hükümetin kurulması ve Osmanlı İmparatorluğu'nun yıkılarak yerine Türkiye Cumhuriyeti'nin kurulmas1 hakkında bilgiler vermesi,

- $\quad$ Alanda özgün bir çalışma olması nedeniyle önem kazanmaktadır.

\section{3. Çalışmada Evren ve Örneklem}

Birinci Dünya Savaşı'nın sürdüğü yıllarda iktidarı ele geçiren Bolşevik hükümet lideri Lenin'in ve yine aynı savaştan yenik düşen Osmanlı İmparatorluğu'nun küllerinden yeni bir devlet ortaya çıkaran Atatürk'ün propaganda posterleri, çalışmanın evrenini oluşturmaktadır. Bütün propaganda afişlerini incelemek hem sayıca çok olduğundan hem de afişlere erişimin kısıtlılığından ötürü yalnızca içinden örneklem amaçlı 4 tane Lenin'in, 4 tane de Atatürk'ün propaganda amaçlı posterleri incelenmiş̧tir. Propaganda afiş̧leri genel olarak aynı içerikte üretildiğinden dolayı her bir lider için 4 adet seçilmiş ve toplamda 8 afiş analize tabi tutulmuştur.

\section{4. Çalışmanın Sınırlıııkları}

Bolşevik lider Lenin ve Türkiye Cumhuriyeti kurucusu Atatürk figürlerinin propaganda amaçlı kullanılmasında gazete, dergi, kitap, kartpostal vb. araçlarda değil de yalnızca posterler üzerinde incelenmeye tabi tutulması çalışmanın temel sınırlılığını içermektedir. Bir diğer sınırlılık Atatürk'ün 4 adet, Lenin'in de 4 adet olmak üzere toplamda 8 adet propaganda afişinin incelenmesidir.

\section{5. Çalışmanın Yöntemi ve Roland Barthes'ın Göstergebilimsel Analiz Yöntemi}

Çalışmada incelenen propaganda afişleri nitel araştırma yöntemleri içinde yer alan göstergebilimsel analize tabi tutulmuştur. Fransız dilbilimci Roland Barthes'ın düzanlam (dénotation) ve yananlam (connotation) kuramları ele alınarak afişlerde kitlelere iletilmek istenen mesajlar incelenmiştir. Aynı zamanda afişler içinde dost ve düşman figürleri oluşturulurken hangi metaforların kullanıldığı da çalışmada gözden geçirilmiştir.

Roland Barthes, modern göstergebilimin bulunmasına yardımcı olmuş ve çevresinde gördüğü medya, moda, sanat, edebiyat, fotoğraf vb. gibi "mitlere" yapısalc1 (semiyotik) yöntemler uygulamıştır. Barthes geliştirdiği göstergebilimsel analiz yöntemiyle iletişim çalışmalarına büyük katkılar sağlamış ve metin çözümlemelerine farklı bir bakış açısı getirmiştir. Barthes'a göre kültürdeki her şey işaret anlamı taşımakta ve özel bir mesaj göndermektedir. Barthes için metin her şeyden önce gelmekte ve metinlerde bulunan göstergelerle oluşan ve anlam taşıyan unsurlar çözümlenerek açığa çıkarılmaktadır. Barthes'a göre her metinin içinde birden fazla metin vardır ve bu metinlerin varlığı bazen açıkça görünürken bazen gizli kalmış bir şekildedir. Bu her metin birbirinden beslenmekte ve yeni anlamlar ortaya çıkarmakta, bu da metinlerarasılık kuramını doğurmaktadır. Barthes ortaya attığı mitolojilerinde bu mesajları deşifre etmenin yöntemlerini açıklamıştır. Barthes mitin bir tür konuşma olduğu iddiasını savunmuş, bunu da Yunanca "mitos" 
(kelime, konuşma, hikaye) kelimesinin anlamına dayandırmıştır (Barthes:1975: 109). Mitler bir iletişim sistemi, mesaj veya anlam biçimidir. Bu da bir anlam veya mesaj taşıması koşuluyla her şeyin bir mit olabileceği anlamına gelmektedir. Dil, insanlardaki evrensel iletişim yöntemi olduğundan dolay1, her şeyi dile dönüştürmek potansiyel olarak mümkündür (Rifat, 2013: 40).

Barthes'ın çözümlemelerinde anlamlama (signification) kavramına bağlı olarak öne çıkan bir başka kavram da yananlam kavramıdır. Yananlam kavramıyla Barthes'ın anlatmak istediği şey ise mitlerdir. Örneğin, kurt sözcüğü düz anlamıyla vahşi, yırtıcı bir hayvanın adıdır. Ancak Türk mitolojisinde kurt sözcügünün mitsel bir anlamı vardır. Aynı zamanda beyaz güvercin de beyaz renkli bir kuş olmasının yanında barışı da simgelemektedir (Güngör, 2016: 247). Barthes'a göre mitler sadece yan anlamsal göstergeleri ön plana çıkarmamakta, aynı zamanda dilin ideolojik yanını da gizleme işlevine sahiptir (Rifat: 48).

Barthes'a göre mitin iki tür işlevi vardır; mit hem gösterendir hem de bildirendir. Mitin resimdeki kısmı hemen geçmekte, ilk anlamlarından sonra başka değerler ifade etmektedirler (Güngör: 247). Bundan dolayı mit sürekli bir değişim ve dönüşüm halindedir. Barthes, fotoğrafları çözümlerken fotoğraflarda ikinci bir anlamın var olduğunu ve bu anlamın da yananlam olarak görülmesi gerektiğini vurgulamaktadır. Böylelikle fotoğraf ve resim bir mit olarak okunabilecek düzeye gelecektir.

Propaganda afişlerinde kullanılan görsel ve sözsel unsurların yanı sıra renkler de büyük bir önem taşımaktadır. Renklere yüklenen anlamlar kültürlere ve ülkelere göre farklılıklar göstermektedir. Örneğin kırmızı rengin toplumların çoğunda aşk ve savaş rengi olarak bilinmesinin yanı sıra Yunan mitolojisinde, savaş tanrısının rengi olarak bilinmektedir. Aynı renk Çin'de kutsal ve şans getiren bir renk olarak sayllırken, Rusya'da ise komünizmin rengi olarak tasvir edilmektedir. Bununla beraber siyah renk çoğu kültürde gücü, kontrolü, zenginliği ve sağlı̆̆ betimlemektedir. Propaganda afişlerinde sıklıkla kullanılan mavi ve sarı renkler ise güven, otorite, barış, umut ve bazı toplumlarda da kraliyeti temsil etmektedir. Yeşil rengin ağırlıklı olarak yeniden doğuş, yeni bir yaşam ve şans anlamları varken, kahverenginin ise kararlılık ve azimlilik anlamları bulunmaktadır. Son olarak afişlerde bir diğer önemli renk olan beyaz ise barış ve temizlik anlamına gelmektedir. ${ }^{3}$

Çalışmada Roland Barthes'ın semiyoloji ve metin hakkındaki çalışmalarından ve yöntemlerinde ön giriş yapılmış; düzanlam, yananlam ve mit kavramlarına bağlı olarak Atatürk ve Lenin'in propaganda afişleri göstergebilimsel analize tabi tutulmuştur.

\footnotetext{
3 “Cultural Meanings of Color and Color Symbolism”, https://www.empower-yourself-with-colorpsychology.com/cultural-color.html , [21.02.2020]. "Visual Color Symbolism Chart by Culture", https://www.lifewire.com/visual-color-symbolism-chart-by-culture-4062177, [21.02.2020].
} 


\section{Lenin'in Propaganda Afişlerinin İncelenmesi}

6.1. Afiş 1: "Yoldaş Lenin Dünyayı Pisliklerden Temizliyor" Adlı Propaganda Afissi ve Göstergebilimsel Analizi

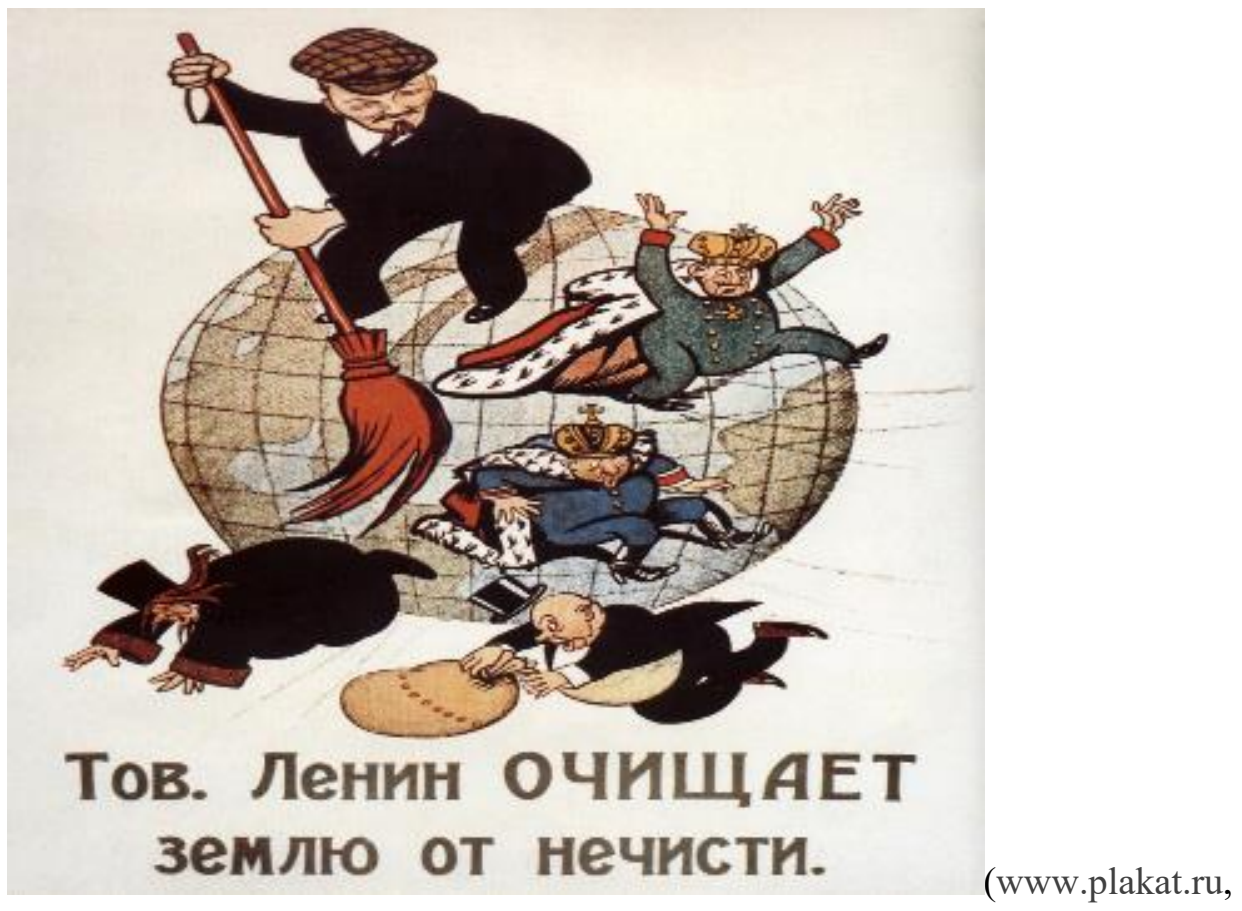

$[28.02 .2020])$

Tablo 1: Düzanlamın gösteren ve gösterilen tablosu (Afiş 1)

\begin{tabular}{lc}
\hline Düzanlamın gösterenleri & Düzanlamın gösterilenleri \\
\hline Lenin & Afişteki şahıs \\
Çarlar, Kapitalist ve Papaz & Din, gericilik, eski düzen, feodalite, \\
Dünya & kapitalizm \\
Süpürge & Yenilik, yeni bir doğuş \\
& Eskiyi temizleyen bir araç
\end{tabular}

Tablo 2: Yananlamın gösteren ve yananlam tablosu (Afiș 1)

Yananlamın gösterenleri

Çerçeve düzenlemesi: Ön plan

Arka plan

Çerçeve: Genel görünüm

Renkler: Siyah

Mavi

Kırmızı
Yananlamın gösterilenleri

Lenin, çarlar, kapitalist ve papaz

Rusya için yeniden başlamış bir yaşam

Lenin'in devrimci ve reformcu özelliği ön planda

İki anlamı vardır. Hem düşman figürleri simgeleyen bir renktir, hem de Lenin'i yücelten bir renktir.

Panislavizm

Çarlık dönemi Rusya ana rengi,

Sovyetler, komünizm

Ünlü Sovyet karikatürist ve ressam Viktor Nikolayeviç Deni tarafından 1920 yılında oluşturulan bu afişte, gülümseyen Lenin'in iki çarın, bir papazın ve para çantasını elinde tutan bir kapitalistin küçük figürlerinin gezegenden nasıl süpürüldüğü betimlenmektedir. 
Afişteki Rusça "нечисть" (neçist) kelimesi SSCB'nin sosyo-politik refahını tehdit eden aşağılık insanlar olarak adlandırılmaktadır. Rus geleneksel anlayışında "neçist" kelimesi iblis, şeytan...vb. İsa'ya düşman doğaüstü güçler anlamına gelmektedir. Kızıl propaganda ise aksine bu sözcügü Hristiyan toplumunun temsilcilerine bağlamakta ve Sovyet toplumunun düşmanları olarak nitelendirmektedir. Afişte Lenin silueti şapka ve süpürge figürleriyle birleştirilmiştir. İş başında olarak resmedilen Lenin yarı proleter bir özellik kazanmıştır.

6.2. Afiş 2: "Lenin Yaşadı, Lenin Yaşıyor, Lenin Yaşayacak" Adı Propaganda Afişi ve Göstergebilimsel Analizi

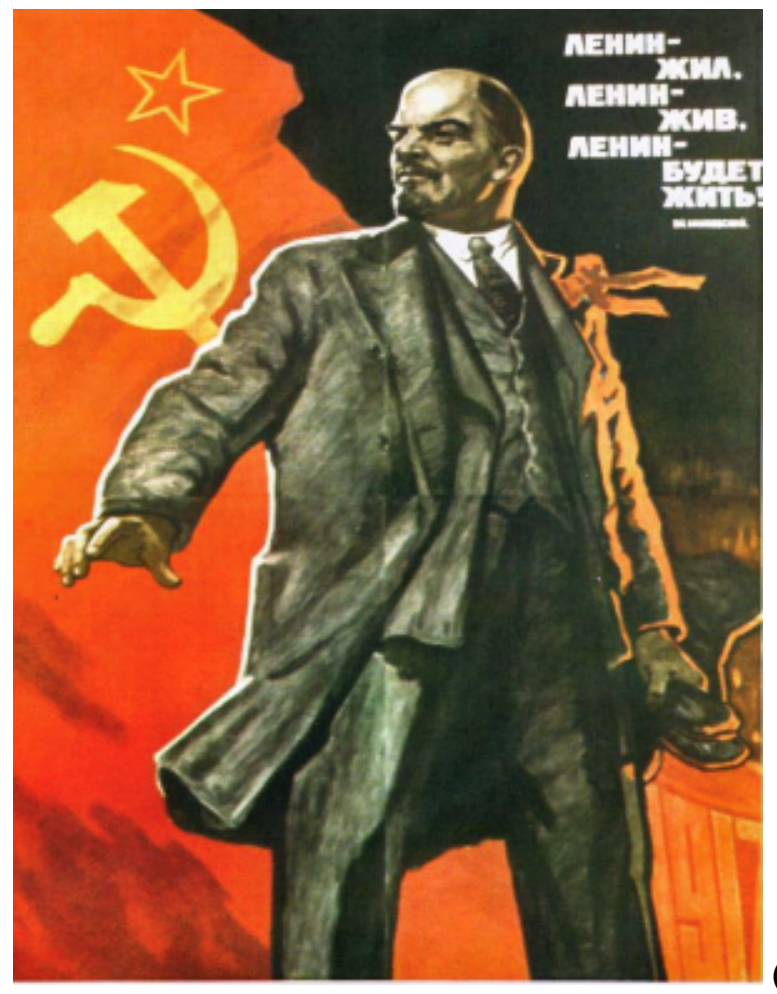

(www.sovposters.ru, [01.03.2020])

Tablo 3: Düzanlamın gösteren ve gösterilen tablosu (Afiş 2)

\begin{tabular}{ll}
\hline Düzanlamın gösterenleri & Düzanlamın gösterilenleri \\
\hline Lenin & SSCB'nin kurucusu, Bolşevik lider \\
Orak ve çekiç & Komünizm, çiftçiler, işçiler \\
Kızıl yıldız & Sosyalizm ve komünizm \\
1917 & Bolşeviklerin iktidarı ele geçirdiği tarih \\
Tablo 4: Yananlamın gösteren ve gösterilen tablosu (Afiş 2) \\
\hline Yananlamın gösterenleri & Yananlamın gösterilenleri \\
\hline Çerçeve düzenlemesi: Ön plan & Dik ve güçlü duran Lenin figürü \\
Arka plan & Sovyetler bayrağı \\
Çerçeveleme: Yakın görünüm & Lenin'in lider özelliği ön planda \\
Renkler: Kırmızı & SSCB, komünizm \\
Siyah & Lenin'in güçlü kişiliği \\
Sarı & SSCB, sosyalizm
\end{tabular}

Afiş, ünlü Sovyet ressamı Viktor Semyonoviç İvanov tarafından 1967 yılında tasarlanmıştır. Beyaz fon üzerinde yazan "Lenin yaşadı, Lenin yaşıyor, Lenin yaşayacak!" yazısı Sovyet şairi 
Vladimir Mayakovski tarafından yazılmış, daha sonra bu söz Lenin için söylenen büyük bir slogan haline dönüşerek ülke geneline yayılmıştır.

Afişte arkasında kızıl renkteki Sovyetler bayrağıyla ve sol altında Sovyetlerin kuruluş tarihi olan 1917 rakamlarıyla duran bir Lenin figürü görülmektedir. Kafasını sağa doğru çevirmiş Lenin, Sovyetlerin ve kendi fikirlerinin daha uzun süre yaşayacağını simgelemektedir.

\subsection{Afiş 3: “Lenin Bayrağı Altında - Zafere Doğru İlerleyin” Adlı Propaganda Afişi ve Göstergebilimsel Analizi}

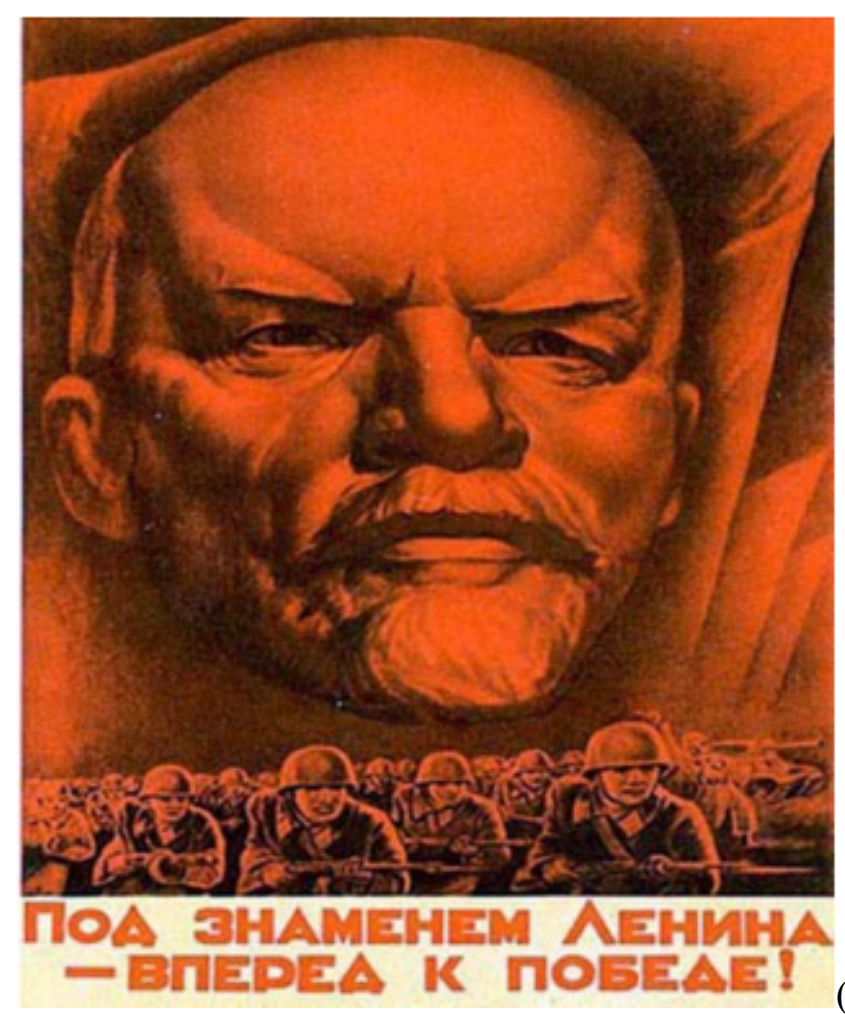

(www.softsalo.com, [01.03.2020])

Tablo 5: Düzanlamın gösteren ve gösterilen tablosu (Afiş 3)

\begin{tabular}{ll}
\hline Düzanlamın gösterenleri & Düzanlamın gösterilenleri \\
\hline Lenin & SSCB kurucu lideri \\
Sovyet askerleri & Savaş, cephe, zafer \\
Silah & Gü̧̧ unsuru \\
Tablo 6: Yananlamın gösteren ve gösterilen tablosu (Afiş 3) \\
\hline Yanalamın gösterenleri & Yananlamın gösterilenleri \\
\hline Çerçeve düzenleme: Ön plan & Savaşmaya hazır ve silah tutan askerler \\
Arka plan & Lenin figürü \\
Çerçeveleme: Genel görünüm & Lenin'in liderlik ve komutanlık özellikleri \\
& ön planda \\
Kırmızı ve siyah renkler & SSCB, komünizm ve sosyalizm
\end{tabular}

Afiş, 1941 yılında ünlü Sovyet ressamı Maksimilian Aleksandroviç Voloşin tarafindan tasarlanmıştır. Afiş, Sovyet vatandaşlarını Nazi işgalcilerine karşı yürütülen mücadelede Lenin partisi etrafında toplanmaya çağırmaktadır. Posterde kırmızı ve siyah renkler ön plandadır. Afişte 
Lenin figürü askerlerin, Sovyet vatandaşlarının üzerinde bir güneş gibi simgelenmektedir. Lenin'in yoluna baş koyulmasını ve zafere ancak onun izinden gidilerek erişileceği tasvir edilmektedir.

6.4. Afiş 4: “Lenin Derken Partiyi İma Ediyoruz, Parti Derken Lenin’i İma Ediyoruz" Adlı Propaganda Afişi ve Göstergebilimsel Analizi

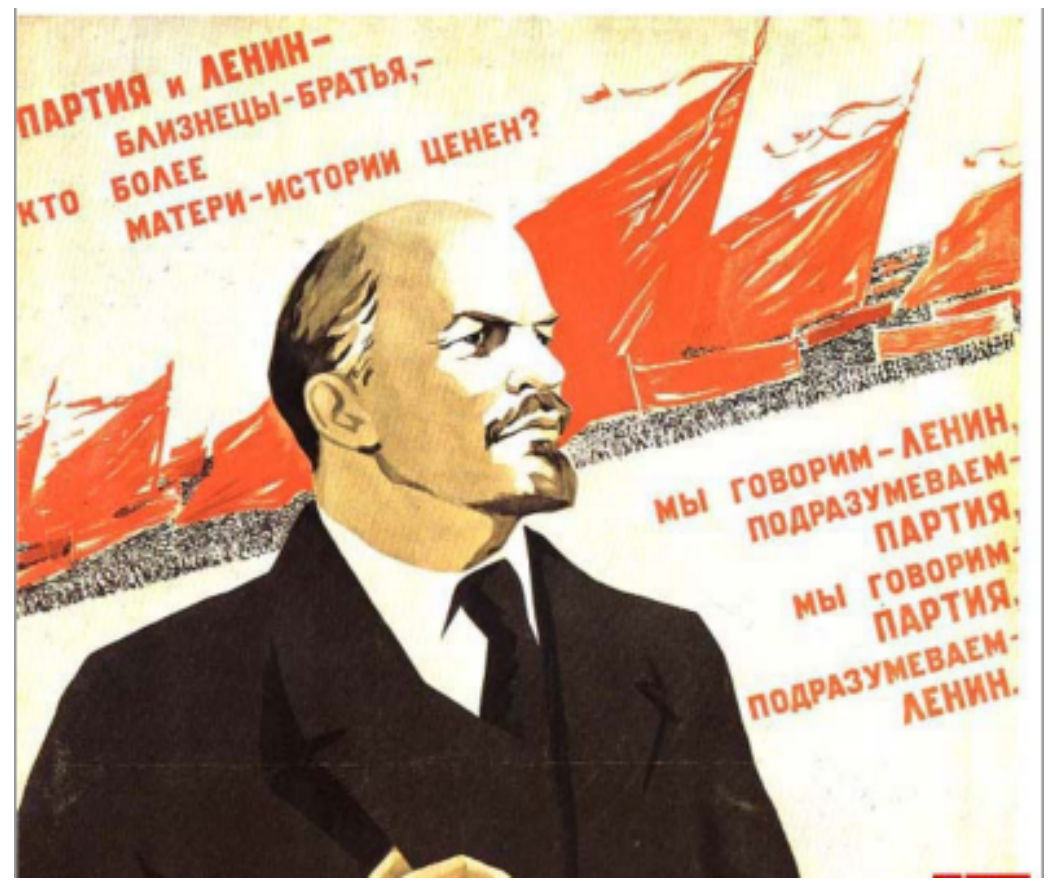

(www.artchive.ru, [01.03.2020])

Tablo 7: Düzanlamın gösteren ve gösterilen tablosu (Afiş 4)

$\begin{array}{ll}\text { Düzanlamın gösterenleri } & \text { Düzanlamın gösterilenleri } \\ \text { Lenin } & \text { SSCB kurucu lideri } \\ \text { Sovyet halkı } & \text { Komünist parti üyesi halk } \\ \text { Kızll bayraklar } & \text { SSCB, komünizm }\end{array}$

Tablo 8: Yananlamın gösteren ve gösterilen tablosu (Afiş 4)

$\begin{array}{lc}\text { Yananlamın gösterenleri } & \text { Yananlamın gösterilenleri } \\ \text { Çerçeve düzenlemesi: Ön plan } & \text { Güçlü ve dik duran Lenin figürü } \\ \text { Arka plan } & \text { K1zıl bayraklar taşıyan Sovyet halkı } \\ \text { Çerçeveleme: Genel görünüm } & \text { Lenin'in lider kimliği ön planda, Sovyet } \\ & \text { halkı ve Komünist Parti üyeleri arka planda } \\ \text { Renkler: Siyah } & \text { Lenin'in güçlü kişiliği } \\ \text { Kırmızı } & \text { SSCB, Komünizm }\end{array}$

Afiş, 1940 yılında ünlü Sovyet ressamları Nina Nikoloyevna Vatolina ve Denisov Nikolay Viktoroviç tarafından tasarlanmıştır. Afişte kırmızı renkte yazılı "Parti ve Lenin ikiz kardeşlerdir. Nitekim, Lenin derken partiyi ima ederiz, parti derken Lenin'i ima ederiz" sözleri ünlü Sovyet şair Mayakovski'ye aittir. Afişte Lenin liderliğinde bütün insanların Komünist partide birleşmelerinin, böylece güçlü bir birlik oluşturacakları belirtilmektedir. Lenin ve Komünist partinin asla birbirinden ayrı tutulmayacağının altı çizilmiştir. 


\section{Atatürk'ün Propaganda Afişlerinin İncelenmesi}

7.1. Afiş 5: "Halaskâran-ı İslam (İslam'ın Kurtarıcıları)" Adı Propaganda Afişi ve Göstergebilimsel Analizi

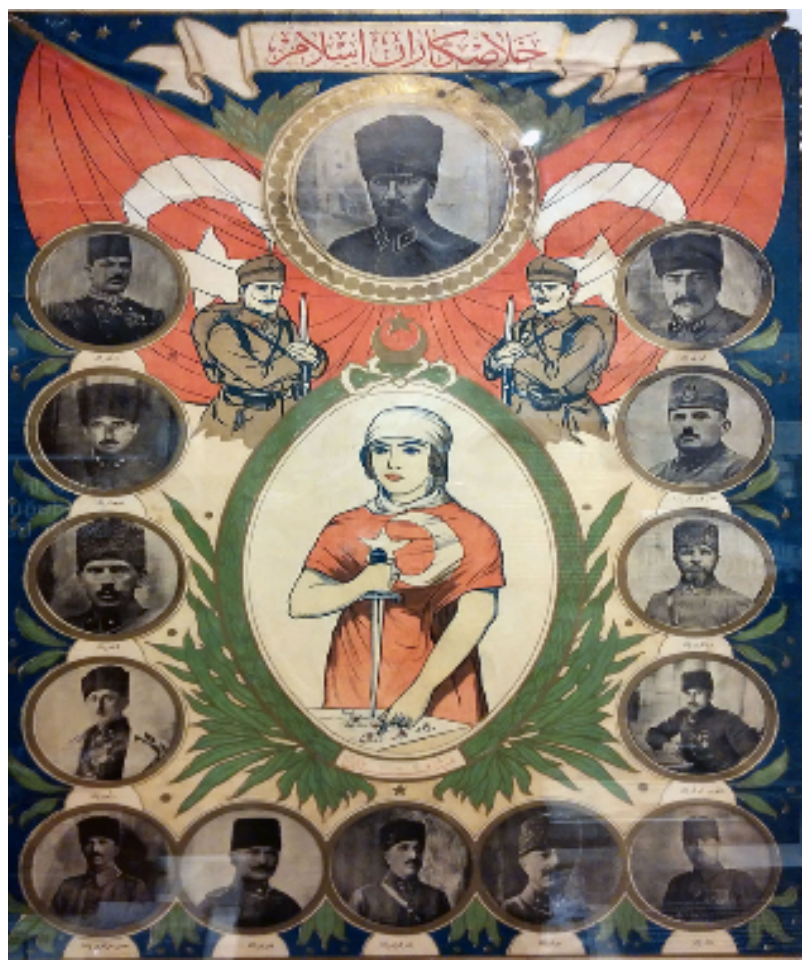

(tr.wikipedia.org, [02.03.2020])

Tablo 9: Düzanlamın gösteren ve gösterilen tablosu (Afiş 5) Düzanlamın gösterenleri

Düzanlamın gösterilenleri

Atatürk

Millî Mücadelenin lideri

Türk bayrağı ve askerler

Atatürk'ün 13 silah arkadaşı

Milliyetçilik, vatan sevgisi

Türk bayrağı giymiş kadın

Atatürk ile beraber mücadele eden askerler

Vatansever Türk kadını

Tablo 10: Yananlamın gösteren ve gösterilen tablosu (Afiş 5)

Yananlamın gösterenleri

Çerçeve düzenlemesi: Ön plan

Arka plan

Çerçeveleme: Genel görünüm

Renkler: Kırmızı

Beyaz

Yeşil
Yananlamın gösterilenleri

Atatürk ve 13 silah arkadaş1

Türk kadını ve Türk askerleri

Atatürk'ün liderlik özelliği ön planda

Bayrak rengi, şehitlerin kanı

Bayrak rengi, ay ve yıldız

Yeni bir yaşam, doğuş, yenilenme

Afiş, 1919 yılında Milli Mücadele döneminin, Kurtuluş Savaşı'nın propaganda afişslerinden biridir. Halaskaran-1 İslam adı verilen bu afiş yalnız 10 adet basılmıştır. Üzerinde Atatürk ve silah arkadaşları yer almaktadır. Afişin başlığında Osmanlıca "İslam'ın Kurtarıcıları" ibaresi bulunmaktadır. Mustafa Kemal Atatürk ve 13 silah arkadaşlarının fotoğrafları afişte ön planda yer almaktadır. Saat yönünün tersine doğru: Mustafa Kemal Atatürk, Rauf Orbay, İsmet İnönü, Cafer Tayyar Eğilmez, Refet Bele, İzzettin Çalışlar, Ömer Fahrettin Türkkan, Fahrettin Altay, Cevat Çobanlı, Halit Karsıalan, Yakup Şevki Subaşı, Nureddin İbrahim Konyar, Kazın Karabekir, Fevzi 
Çakmak bulunmaktadır. Atatürk fotoğrafının altında Türk bayrağı ve iki asker resmi, orta kısımda ise üzerinde ay yıldızlı elbise bulunan, să elinde bir kama, sol eliyle ise Misak-1 Milli sınırlarını gösteren bir kadın resmi bulunmaktadır. Afişteki kadın Türk milletinin şerefini temsil etmektedir. Bununla beraber kadının afişin merkezinde yer alması Türk kadınının gücünü ve Atatürk’ün Türk kadınına verdiği önemi göstermektedir.

7.2. Afiş 6: "1922'de Başlayan Zafer Hala Devam Ediyor” Adlı Propaganda Afiși ve Göstergebilimsel Analizi

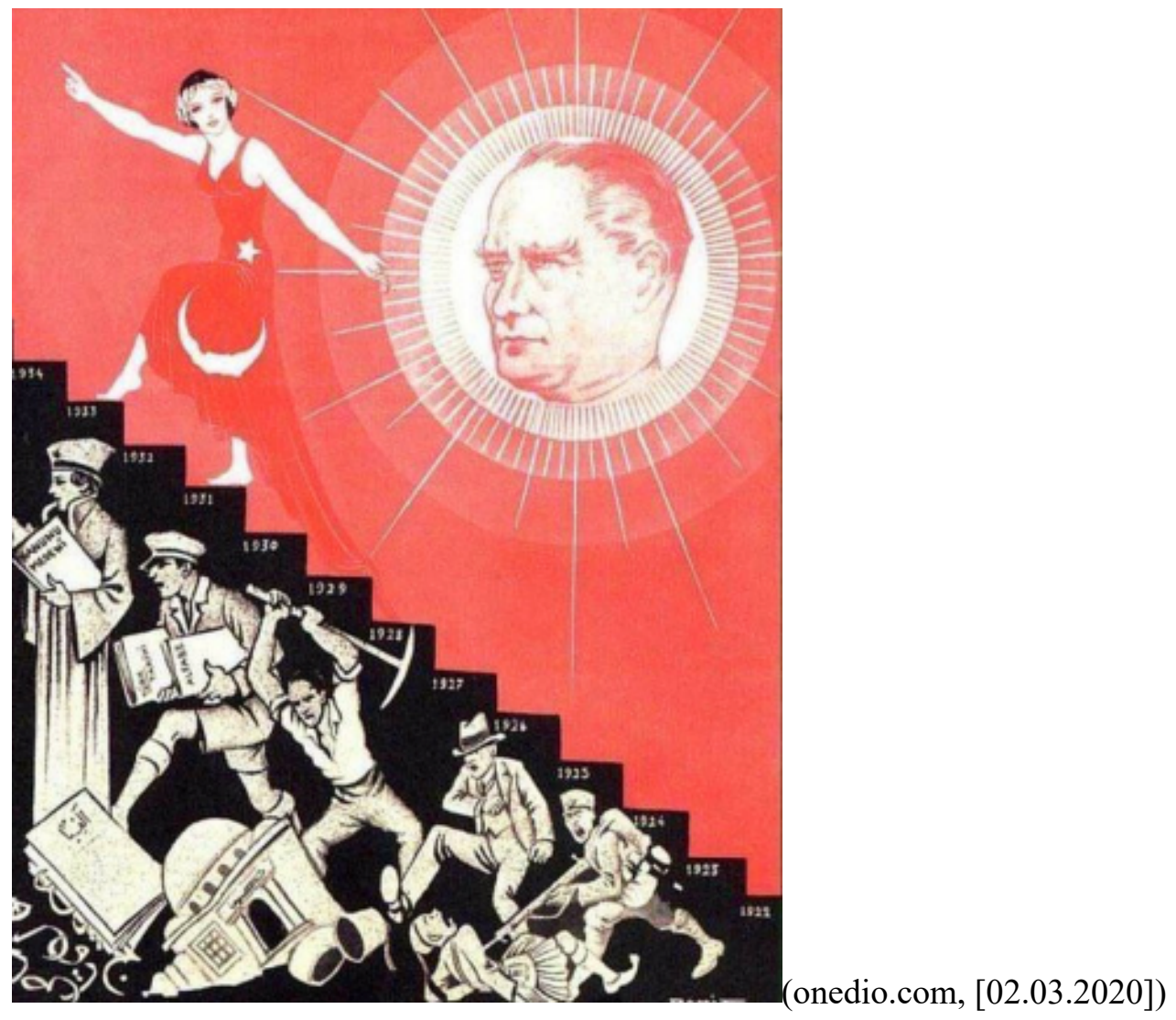

Tablo 11: Düzanlamın gösteren ve gösterilen tablosu (Afiş 6)

\begin{tabular}{|c|c|}
\hline Düzanlamın gösterenleri & Düzanlamın gösterilenleri \\
\hline Atatürk & Cumhuriyetin kurucu lideri \\
\hline Türk bayrağı giymiş kadın & İlericilik \\
\hline $\begin{array}{l}\text { Hukukçu, işçi, öğretmen, yeni modern } \\
\text { insan asker }\end{array}$ & Çağdaşlık, modern ülkenin yeni insanları \\
\hline Eski kitap, medrese, fes, Yunan askeri & Eski düzen, düşman asker \\
\hline \multicolumn{2}{|c|}{ Tablo 12: Yananlamın gösteren ve gösterilen tablosu (Afiş 6) } \\
\hline Yananlamın gösterenleri & Yananlamın gösterilenleri \\
\hline Çerçeve düzenlemesi: Ön plan & Atatürk ve Türk kadını \\
\hline Arka plan & $\begin{array}{l}\text { Modern ülkenin hedeflenen yeni tip } \\
\text { insanları, eski düzenin atılmak istenen gelenekleri }\end{array}$ \\
\hline Çerçeveleme: Genel görünüm & Atatürk ve reformları ön planda \\
\hline Renkler: Kırmızı & Bayrak rengi, şehitlerin kanı \\
\hline Beyaz & Bayrak rengi, ay ve yıldız \\
\hline Siyah & Eski düzen \\
\hline
\end{tabular}


Afiş, karikatürist Ramiz Gökçe tarafından 1933 yılında oluşturulmuştur. Afişte Türk kadını asil ve güçlü olarak resmedilmiş ve Türk milletine yol gösterici bir şekilde betimlenmiştir. Afişte Türk kadını bir eliyle güneşin içindeki Atatürk’ü tutmakta, diğer eliyle ileriyi göstermektedir. Aynı zamanda belli tarihler yazılı merdivenleri çıkmaktadır. Tarihler 1922'den başlayarak 1934'e kadar uzanmaktadır. Bu merdivenler, Türkiye'nin muhasır medeniyetler seviyesine erişmesi yolundaki inkılapları resmetmektedir. Yunan ordusunun denize dökülmesi, harf devrimi, medreselerin kapatılması ve medeni kanuna kadar cumhuriyetin bütün geçirdiği yollar bu afiște ortaya koyulmuştur. Afişte, merdivenin altında elinde medeni kanunu tutan bir hukukçu, eski alfabeyi ayaklar altına alarak yeni alfabeyi elinde tutan bir kişi, medreseyi baltayla yıkan bir vatandaş, takke ve fesi ezerek modern şapka takan bir şahıs ve Yunan askerine silah dayayan bir Türk askeri bulunmaktadır.

\subsection{Afiş 7: "Yeni Türk Harfleri ve Atatürk" Adlı Propaganda Afişi ve} Göstergebilimsel Analizi

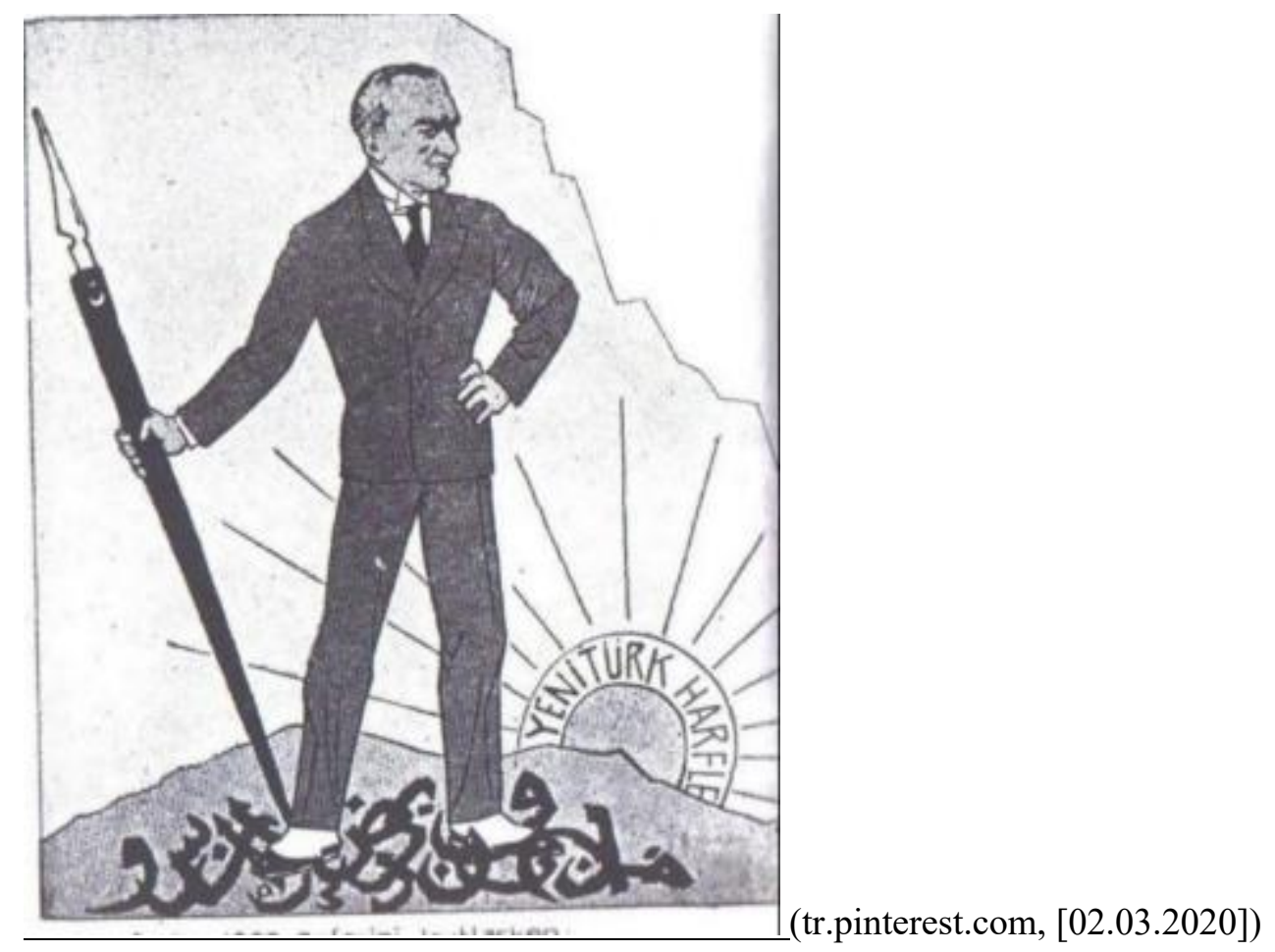

Tablo 13: Düzanlamın gösteren ve gösterilen tablosu (Afiş 7)

\begin{tabular}{lll}
\hline Düzanlamın gösterenleri & Düzanlamın gösterilenleri \\
\hline Atatürk & Yeni cumhuriyetin kurucu lideri \\
Kalem & Modern eğitim, yeni sistem \\
Güneş & Yeniden doğuş, yenilik \\
Arap harfleri & Eski düzen & \\
Tablo 14: Yananlamın gösteren ve gösterilen tablosu (Afiş 7) & Yananlamın gösterilenleri \\
\hline Yananlamın gösterenleri & Atäürk ve kalem & \\
Çerçeve düzenlemesi: Ön plan & Harf devrimiyle beraber artı \\
Arka plan & kullanılmamaya baslanan Arap harfleri \\
& Atatürk’ün reformist özelliği ön planda \\
Çerçeveleme: Genel görünüm &
\end{tabular}




$\begin{array}{ll}\text { Renkler: Siyah } & \text { Eski gelenekler ve yeni düzen } \\ \text { Beyaz } & \text { Yenilik, çağdaşlık }\end{array}$

Afişte, harf devrimini gerçekleştiren Atatürk dağın tepesinde elinde kalemle güçlü bir şekilde durmaktadır. Ardından güneş açmakta ve güneşte ise "Yeni Türk Harfleri” yazmaktadır. Afişte aynı zamanda Arap harfleri Atatürk'ün ayaklarının altında çiğnenmiş bir şekilde resmedilmiştir. 1 Kasım 1928 tarihinde gerçekleşen Harf Devrimi ile beraber "Yeni Türk harflerinin kabul ve tatbiki hakkında Kanun"un kabul edilmesi ve yeni alfabenin yerleştirilmesi süreci başlamıştır. Bu yasanın kabulünün ardından Arap harfleri esaslı Osmanlı alfabesi kaldırılmış ve yerine Latin harflerini esas alan Türk alfabesi yürürlüğe konulmuştur. Atatürk'ün harf devrimindeki bu başarısı afişin temel konusudur.

\subsection{Afiş 8: “İnkılaplar ve Atatürk” Adlı Propaganda Afişi ve Göstergebilimsel} Analizi

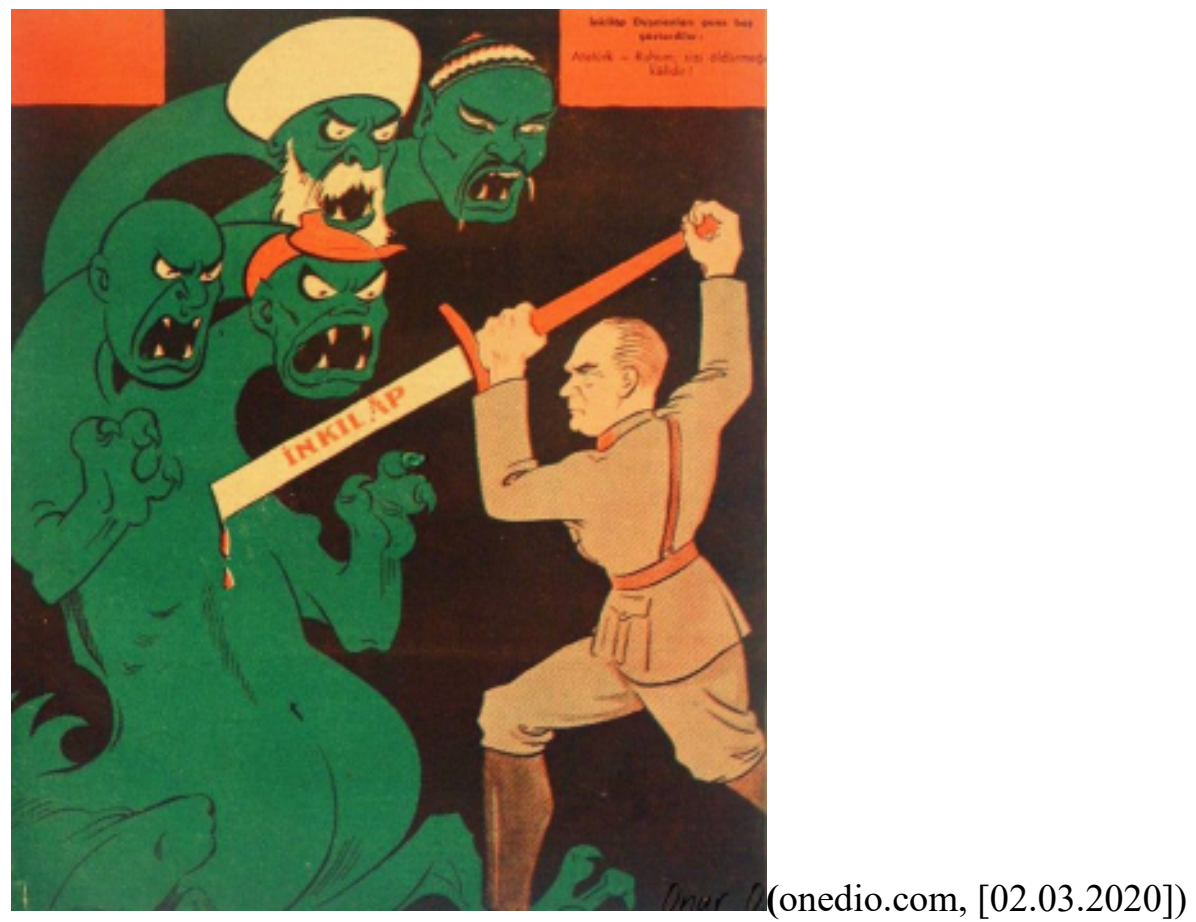

Tablo 15: Düzanlamın gösteren ve gösterilen tablosu (Afiş 8)

Düzanlamın gösterenleri

Atatürk

Dört başlı canavar figürü

Düzanlamın gösterilenleri

Cumhuriyetin kurucu figürü, eski geleneklerle mücadele eden bir lider

İslamcılık, Turancılı, komünizm ve

Kılıç

kapitalizme karşıtlık

Mücadele

Tablo 16: Yananlamın gösteren ve gösterilen tablosu (Afiș 8)

\section{Yananlamın gösterenleri}

Çerçeve düzenlemesi: Ön plan

Arka plan

Çerçeveleme: Genel görünüm

Renkler: Yeşil

Kırmızı

Kahverengi

\section{Yananlamın gösterilenleri}

Atatürk

Dört başlı bir yaratık

Atatürk'ün mücadeleci özelliği ön planda

Kötülük, düşman

Türk bayrak rengi, şapkada komünizm temsil edilmektedir.

Mücadele, kararlılık 
Afişte, Atatürk elinde "İnkılap" yazan bir kılıçla dört başlı yaratıkla mücadele etmektedir. Afişin sağ üst köşesinde "İnkılap düşmanları gene baş gösterdiler. Atatürk- ruhum sizi öldürmeğe kafidir" yazısı yer almaktadır. Afişteki dört başlı yaratıktan kafasında takke olan İslamizmi, şapka ve bıyıklı olan Turancılığı, kırımı şapka takmış olan komünizmi, kel olan ise kapitalizmi temsil etmektedir. Atatürk elindeki kılıcı bu yaratığa saplamakta ve Atatürk döneminde yapılan inkılaplara karşı düşman bildiği bu görüşlerle mücadelesini yürütmektedir.

\section{Sonuc}

Afişlerin propaganda amaçlı kullanılması uzun yıllar boyunca belirli bir ideolojiyi kitlelere aşılamak, kendi propagandasını yapmak ve toplumu bir kanaat çevresinde toplamak isteyen liderler için sıklıkla başvurulan bir yöntem olmuştur. Ülkeler dünya savaşları esnasında kendi halklarını savaşa çekmek ve halihazırda girdikleri savaşta halkın desteğini sağlamak için propaganda afişlerinden yararlanmışlardır. Birinci Dünya Savaşı sırasında üretilen propaganda afişleri kimilerini dost olarak gösterirken kimilerini de düşman olarak betimlemiştir. Aynı şekilde propaganda afişleri yapılan ülke liderleri, bu afişlerde üstün güçlere sahip birer varlık olarak betimlenmişler, kahraman ve kurtarıcı unsur olarak slogan sözlerle halka lanse edilmişlerdir.

1917 devrimi sonrası kurulan Sovyet Sosyalist Cumhuriyetler Birliği'nin fikir babası ve kurucu lideri Lenin olmuştur. Bu devrimin öncesine kadar Rusya'da ağır ve çalkantılı yıllar yaşanmıştır. Önce 1905 Devrimi yaşanmış, burada başarısız olunmuş, ardından 1917 Şubat Devrimi gerçekleştirilerek Çarlık sistemi devrilmiş, yerine Geçici Hükümet gelmiştir. Bolşevik ideoloji Geçici Hükümeti hiçbir zaman desteklememiş, iktidarı ele alacağ 1 Ekim 1917'ye kadar yurtdışında bulunan Lenin liderliğinde faaliyetlerine aktif bir şekilde devam etmiştir. Lenin'in Ne Yapmalı, Devlet ve Devrim, Nisan Tezleri adlı üç önemli eseri Bolşevik saflarına olduğu kadar işçi ve köylü sınıfına da devrim ruhunu aşılamış ve Ekim Devrimi'ne giden yolda yol gösterici eserler olmuşlardır. $\mathrm{Bu}$ doğrultuda Lenin figürünün yer aldığ 1 propaganda afişlerini incelerken "yoldaş" değil de bir "kurucu lider" olarak tasvir edildiği görülmüştür. Lenin bu afişlerde, gerek ülkeyi Çarlık düzeninden kalan ve tasfiye edilmesi gerektiğini düşündüğü kötü ruhlardan (Çar, kapitalist, din adamı vb.) kurtaran ve büyük bir temizlik gerçekleştiren biri olarak görülmekte, gerekse Sovyet devletini bütün dünyaya duyuran güçlü bir lider olarak lanse edilmektedir. Savaşı betimleyen afişlerin birçoğunda Lenin figürü askerlerin arkasında büyük bir güç olarak gösterilmekte ve yapılan savaşlarda "Lenin liderliğinde, Lenin bayrağı altında vb.) ifadeler kullanılmaktadır. Bu da ülke içinde yapılacak her hareketin, hedeflenen her planın Lenin'in direktifleri ve görüşleri doğrultusunda gerçekleştirileceğini gösterir niteliktedir. Propaganda afişlerinde aynı zamanda Lenin'in kurduğu "Rusya Sosyal Demokrat İşçi Partisi" için üye toplanmakta ve bu partinin Lenin'in görüşlerinden hiçbir zaman ayrılmayacağı, onun görüşlerinin yüceltilerek sürdürüleceği halka bildirilmiştir. Dolayısıyla ne kadar fazla üye toplanırsa Lenin'in partisi o kadar fazla yaşayacağ 1 düşüncesi hakimdir.

Aynı örnek Osmanlı İmparatorluğu'nun son dönemi Türkiye Cumhuriyeti'nin kuruluş aşamasında da görülmektedir. Fransız İhtilali sonucu topraklarında milliyetçilik akımları baş gösteren, Avrupa ve Rusya tarafindan ağır savaşlara mahkum edilen Osmanlı İmparatorluğu'nun son dönemlerinde bir asker olan Atatürk, cephelerde verdiği yoğun mücadeleler ve başlattı̆g 1 Türk Kurtuluş Savaşı sonucu ülkenin kurucu lideri konumuna gelmiştir. Yeni Cumhuriyetin kurucu lideri olarak Atatürk figürünün yer aldığı propaganda afiş̧leri analize tabi tutulmuş, bu analiz sonucunda Atatürk'ün afişlerde güçlü, yol gösteren ve Türkiye'yi her zaman ileri götürmeye çalışan bir lider olarak gösterildiği sonucuna ulaşılmıştır. Asker arkadaşlarıyla beraber Türk Kurtuluş Savaşı'nın ilk afiş örneklerinden sayılan "İslam'ın Kurtarıcıları" adlı afişte Atatürk en tepedeki kilit isim olarak yerini almış ve diğer silah arkadaşları da yanındaki yardımcıları, yol arkadaşları olarak resmedilmişlerdir. Aynı şekilde afişlerde en çok işlenen temalar Atatürk'ün devrim ve inkılaplarıdır. Dönemin afişlerinde Atatürk ile beraber Türk Medeni Kanunu, şapka ve kıyafet, yeni Türk harflerinin kabulü, kadın hakları, tekke ve zaviyelerin kapatılması gibi inkılaplar geniş yer tutmuştur. 
Atatürk döneminde yapılan bu inkılaplara karşı çıkan taraflar ve Atatürk'ün onlara karş1 yürüttüğü mücadeleler de dönemin afişlerinde resmedilen bir diğer unsurdur. Yeni kurulan bu iki devletin liderlerinin ve ideolojik görüşlerinin yer aldığı propaganda afişleri yıllar boyunca üretilerek ülkenin çeşitli yerlerine asılmış, gazete ve dergi gibi çeşitli kitle iletişim araçlarının kapaklarında yayınlanmıştır.

Atatürk ve Lenin'in propaganda afişlerinin Barthes'in göstergebilimsel yöntemiyle analiz edildiği bu çalışmada, iki liderin kendi ülkelerindeki bazı ideolojilere karşı yürüttükleri mücadelenin resmedildiği propaganda afişleri analiz edilerek incelenmeye sunulmuştur. Özellikle Lenin'in ülke içinde karşı olduğu zengin toprak sahipleri (kulaklar), Çar soyu ve dini liderler bu afiş̧lerde düşman unsur olarak nitelendirilmiştir. Aynı düşman örnek Atatürk için inkılaplarına karşı gelen herkes ve tüm ideolojiler olarak resmedilmiş̧ir. Bu doğrultuda incelenen propaganda afişleri, liderlerin dünya görüşünü ve yaptığı mücadeleleri göstermesi bakımından önem taşımaktadır. Buna karşın iki ülke liderinin yer aldığı afişler geneli temsil eden ve aynı görüşte üretilen afişlerin önemli örnekleri oldukları için bu alana katkı sağlayacağı kanaatine varılmaktadır.

\section{Kaynakça}

Akarcalı, S. (2003). İkinci Dünya Savaşı'nda İletişim ve Propaganda. İmaj Yayınları.

Akçura, G. (1994). Afişlerde Tiyatro. Sky Life Dergisi, THY, İstanbul Yayınları, sayı 129, 28-31.

Atatürk, M.K. (1989). Nutuk. Cilt 1-2-3. Türk Tarih Kurumu Yayınları.

Barthes, R. (1975). Mythologies. (6. Bask1). Çev. Annette Lavers. New York: Hill and Wang.

Bektaş, A. (2002). Siyasal Propaganda. Bağlam Yayınc1lık.

Berkes, N. (2013). Türkiye'de Çağdaşlaşma. (19. Baskı). Yapı Kredi Yayınları.

Brown, J. A. C. (1992). Siyasal Propaganda. Çev. Yusuf Yazar. Ağaç Yayıncılık.

Chambers, R. (1983). Art and Propaganda In An Age Of War: The Role Of Posters. Scientia Militaria, South African Journal of Military Studies, 4(13), 54-59. https://doi.org/10.5787/13-4-543

Çakı, C., Gülada, M.O. (2018). 2. Dünya Savaşı'nda Kullanılan Sovyet Propaganda Posterlerinde Coşku Çekiciliği Bağlamında Kadınların Temsili Akdeniz Kadın Çalışmaları ve Toplumsal Cinsiyet Dergisi, 1(2), 157-176.

Çaycı, A. (2002). Gazi Mustafa Kemal Atatürk Milli Bağımsızlık ve Çağdaşlaşma Önderi (Hayatı ve Eseri). Atatürk Kültür, Dil ve Tarih Yüksek Kurumu Atatürk Araştırma Merkezi Yayınları.

Ekici, Y. (2017). Bolşevik İhtilali'nin Ortaya Çıkması ve Sebepleri, Fırat Üniversitesi Sosyal Bilimler Dergisi, 27(1), 265-275. https://doi.org/10.18069/firatsbed.346466

Güngör, N. (2016). Iletişsim Kuramlar ve Yaklaşımlar. (3. Bask1). Siyasal Kitabevi.

Hitler, A. (1998). Kavgam. Çev. Selam Uğurlu. Kamer Yayınları.

İnceoğlu, Ç. (2015). Politik Bir Silah: Birinci Dünya Savaşı'nda İngiltere, Fransa, Almanya ve ABD'de Propaganda Filmciliği. Karadeniz Teknik Üniversitesi Iletişim Araştırmaları Dergisi, 3(10), 70-84.

Jowett, Garth. S., \& O’Donnell, V. (2012). Propaganda and Persuasion (5 bask1). Sage Publications.

Kenez, P. (1985). The Birth of the Propaganda State. Soviet Methods of Mass Mobilization, 19171929. Cambridge University Press. 
Kılıç, A. (1955). Atatürk'ün Hususiyetleri. Sel Yayınları.

Koloğlu, O. (1994). Osmanlı'dan Günümüze Türkiye'de Basın. İletişim Yayınları.

Kuruoğlu, H. (2006). Propaganda ve Özgürlük Aracı Olarak Radyo. Nobel Yayıncılık.

Lewis, B. (1993). Modern Türkiye’nin Doğuşu. (5. Baskı). Çev. Metin Kıratlı. Türk Tarih Kurumu Basimevi.

Ланцов, С.А. (2017). Октябрьская Революция 1917 Года: Замыслы и Результаты. Вестник Санкт-Петербургского Университета Поитология. 10(4), 289-300. https://doi.org/10.21638/11701/spbu06.2017.401

Орлов А.С., Георгиев В.А., Георгиева Н.Г., Сивохина Т.А. (2017). История России. (4-е издание). Проспект.

Qualter, Terence. H. (1962). Propaganda and Psychological Warfare. Random House.

Rifat, M. (2013). Açıklamalı Göstergebilim Sözlügü: Kavramlar, Yöntemler, Kuramcılar, Okullar. Türkiye İş Bankası Kültür Yayınları.

Садуль, Ж. (1990). Записки о Большевистской Революиии (Октябрь 1917- Январь 1919). Историко-Литературный Архив.

Seidman S. (2008), Posters, Propaganda, and Persuasion in Election Campaigns Around The World and Through History. Peter Lang Publishing.

Sürmeli, S. (2001), Türk-Gürcü Ilisşkileri (1918-1921). Atatürk Araştırma Merkezi.

Tepecik, A. (2002), Grafik Sanatlar Tarih Tasarım Teknoloji. Detay ve Sistem Ofset.

Topuz, H. (1991). Siyasal Reklamcllık. Cem Yayınevi.

Türk Dil Kurumu. (1998). Türkçe Sözlük, Türk Dil Kurumu Yayınları.

Ulusoy, N. B. (2004). Azerbaycan Siyasi Muhaceretinin İstanbul'daki Basin Etkinliklerinin (19231931) Катиоуи Oluşturmadaki Rolü. İstanbul Üniversitesi İletişim Yayınları.

\section{Çevrimiçi Kaynaklar}

www.artchive.ru, (2020, Mart 01)

onedio.com, (2020, Mart 02)

tr.pinterest.com, (2020, Mart 03)

www.plakat.ru, (2020, Şubat 28)

www.softsalo.com, (2020, Mart 01)

www.sovposters.ru, (2020, Mart 03)

tr.wikipedia.org, (2020, Mart 02)

https://www.lifewire.com/visual-color-symbolism-chart-by-culture-4062177, (2020, Şubat 21)

https://www.empower-yourself-with-color-psychology.com/cultural-color.html, (2020, Şubat 21)

https://www.marxists.org/russkij/lenin/1917/0407a.htm , (2020, Şubat 21) 